\title{
Article \\ $\alpha$-Glucosidase Inhibitory Activity and Anti-Adipogenic Effect of Compounds from Dendrobium delacourii
}

\author{
May Thazin Thant ${ }^{1,2}$, Hnin Ei Ei Khine ${ }^{3}{ }^{\circledR}$, Justin Quiel Lasam Nealiga ${ }^{3}$, Nutputsorn Chatsumpun ${ }^{4}$, \\ Chatchai Chaotham ${ }^{3,5, * \mathbb{C}}$, Boonchoo Sritularak ${ }^{1,6, * \mathbb{C}}$ and Kittisak Likhitwitayawuid ${ }^{1}$ (D)
}

1 Department of Pharmacognosy and Pharmaceutical Botany, Faculty of Pharmaceutical Sciences, Chulalongkorn University, Bangkok 10330, Thailand; drmaythazinthant@gmail.com (M.T.T.); kittisak.1@chula.ac.th (K.L.)

2 Department of Pharmacognosy, University of Pharmacy, Yangon 11031, Myanmar

3 Department of Biochemistry and Microbiology, Faculty of Pharmaceutical Sciences, Chulalongkorn University, Bangkok 10330, Thailand; hnineieikhine12@gmail.com (H.E.E.K.); jquieln@gmail.com (J.Q.L.N.)

4 Department of Pharmacognosy, Faculty of Pharmacy, Mahidol University, Bangkok 10400, Thailand; nutputsorn.cha@mahidol.ac.th

5 Preclinical Toxicity and Efficacy Assessment of Medicines and Chemicals Research Unit, Faculty of Pharmaceutical Sciences, Chulalongkorn University, Bangkok 10330, Thailand

6 Natural Products for Ageing and Chronic Diseases Research Unit, Faculty of Pharmaceutical Sciences, Chulalongkorn University, Bangkok 10330, Thailand

* Correspondence: cchoatham@gmail.com (C.C.); boonchoo.sr@chula.ac.th (B.S.)

Citation: Thant, M.T.; Khine, H.E.E.; Nealiga, J.Q.L.; Chatsumpun, N.;

Chaotham, C.; Sritularak, B.;

Likhitwitayawuid, K. $\alpha$-Glucosidase Inhibitory Activity and

Anti-Adipogenic Effect of

Compounds from Dendrobium

delacourii. Molecules 2022, 27, 1156.

https://doi.org/10.3390/

molecules27041156

Academic Editor: Jacqueline

Aparecida Takahashi

Received: 18 January 2022

Accepted: 8 February 2022

Published: 9 February 2022

Publisher's Note: MDPI stays neutral with regard to jurisdictional claims in published maps and institutional affiliations.

Copyright: () 2022 by the authors. Licensee MDPI, Basel, Switzerland. This article is an open access article distributed under the terms and conditions of the Creative Commons Attribution (CC BY) license (https:// creativecommons.org/licenses/by/ $4.0 /)$.

\begin{abstract}
Chemical investigation of Dendrobium delacourii revealed 11 phenolic compounds, and the structures of these compounds were determined by analysis of their NMR and HR-ESI-MS data. All compounds were investigated for their $\alpha$-glucosidase inhibitory activity and anti-adipogenic properties. Phoyunnanin E (10) and phoyunnanin C (11) showed the most potent $\alpha$-glucosidase inhibition by comparing with acarbose, which was used as a positive control. Kinetic study revealed the non-competitive inhibitors against the enzyme. For anti-adipogenic activity, densifloral B (3) showed the strongest inhibition when compared with oxyresveratrol (positive control). In addition, densifloral B might be responsible for the inhibition of adipocyte differentiation via downregulating the expression of peroxisome proliferator-activated receptor gamma (PPAR $\gamma$ ) and CCAAT enhancerbinding protein alpha $(\mathrm{C} / \mathrm{EBP} \alpha)$, which are major transcription factors in adipogenesis.
\end{abstract}

Keywords: Dendrobium delacourii; Orchidaceae; $\alpha$-glucosidase; anti-adipogenic; densifloral B; phoyunnanin E; phoyunnanin C

\section{Introduction}

Diabetes mellitus (DM) is a chronic metabolic disorder characterized by a high level of blood glucose resulting from a relative or absolute deficiency of insulin action. Type II is the most common type of diabetes, caused by $\beta$-cell dysfunction and insulin resistance [1]. The inhibition of $\alpha$-glucosidase is effective for the treatment of type II diabetes [2]. $\alpha$-Glucosidase is a membrane-bound enzyme produced from the epithelial cells of the small intestine. This enzyme is capable of converting starch and disaccharides into monosaccharides (glucose). Thus, glucose absorption can be reduced by inhibition of this enzyme, and postprandial blood glucose levels can also be decreased [3,4].

The relation between diabetes and obesity is well established in both traditional and modern therapy. The World Health Organization (WHO) estimates that $44 \%$ of diabetes cases are associated with overweightness and obesity [5]. Obesity is a risk factor of type 2 diabetes, coronary heart disease, and hypertension and is becoming a major health problem [6]. As a complex multifactorial chronic disease, obesity is characterized by an excessive adipocyte tissue mass. Adipogenesis is the process of cell differentiation during which fibroblast-like preadipocytes develop into mature adipocytes. Recently, the inhibition 
of adipogenesis has been proposed as a promising anti-obesity approach [7]. Moreover, anti-obesity is able considerably to reduce the prevalence rate of type 2 diabetes [8].

Currently, drugs from natural sources that specifically inhibit peroxisome proliferatoractivated receptor gamma (PPAR $\gamma)$ and CCAAT enhancer-binding protein alpha $(\mathrm{C} / \mathrm{EBP} \alpha)$ expression are being targeted for the treatment of obesity [9]. PPAR $\gamma$ and C/EBP $\alpha$ increase adipocyte differentiation by activating the gene transcription for generating the adipocyte phenotype [10]. The anti-adipogenic activities of several natural compounds such as catechin [11] and procyanidin [12] via the downregulation of C/EBP $\alpha$ and PPAR $\gamma$ have been reported. Moreover, AMP-activated protein kinase (AMPK) is a common regulator that is involved in various lipid metabolisms [13], and the regulation of the AMPK signaling pathway is essential for anti-obesity [14]. The activation of AMPK can downregulate adipogenic key transcription factors such as PPAR $\gamma$ and $\mathrm{C} / \mathrm{EBP} \alpha$, resulting in the suppression of adipocyte differentiation [15]. Acetyl-CoA carboxylase (ACC) is also responsible for the reduction in fatty acid synthesis [16]; in other words, fat accumulation is inhibited by the activation of ACC $[17,18]$. Adipogenesis can be inhibited by increasing the phosphorylation of both AMPK and ACC [19]. Protein kinase B (Akt) and glycogen synthase kinase-3 beta (GSK3 $\beta$ ) are important protein kinases in adipogenesis. The activation of Akt is associated with phosphorylated GSK $3 \beta$ triggering adipogenesis via upregulating $\mathrm{C} / \mathrm{EBP} \alpha$ and $\operatorname{PPAR} \gamma[20,21]$.

The drugs currently available for the treatment of diabetes and obesity are accompanied by severe adverse effects such as insomnia, headache, hypoglycemia, weight gain, constipation, and renal damage [22,23]. There are increasing reports of natural drugs from plant sources, due to their lesser side-effects. Dendrobium species are widely used in traditional medicine for the treatment of various diseases, as they possess a variety of pharmacological properties, such as being antidiabetic, antioxidant, anti-inflammatory, antimicrobial, immunomodulatory, and anticancer [24]. In China, Dendrobium has been used as traditional medicine for thousands of years as source of tonic, astringent, analgesic, antipyretic, and anti-inflammatory action [25,26]. About 41 species of the Dendrobium genus have been recorded in traditional Chinese medicine (TCM); of these, 30 species are collectively known under the Chinese name 'shihu' and are used for nourishing the stomach and increasing bodily fluid production [27]. Some species of this genus have been used in Thai traditional medicine, including D. cumulatum, D. draconis, D. indivisum, D. trigonopus, and D. leonis [28].

Dendrobium delacourii, named 'Ueang Dok Ma Kham' in Thai, belongs to the family Orchidaceae (Figure 1a). The common name is Delacour's dendrobium, and the plant is native to Thailand, Vietnam, Laos, and Myanmar. There is no previous study on the phytochemical constituents and biological activities of this plant. Our screening of the methanolic extract of $D$. delacourii exhibited $\alpha$-glucosidase inhibition $(80 \%$ inhibition at $100 \mu \mathrm{g} / \mathrm{mL}$ ). It also showed an inhibitory effect on adipocyte differentiation in 3T3-L1 cells ( $51 \%$ inhibition at $5 \mu \mathrm{g} / \mathrm{mL}$ ). In this study, we report the phytochemical constituents of $D$. delacourii, along with their inhibitory effects on $\alpha$-glucosidase and adipocyte differentiation. 
(a)

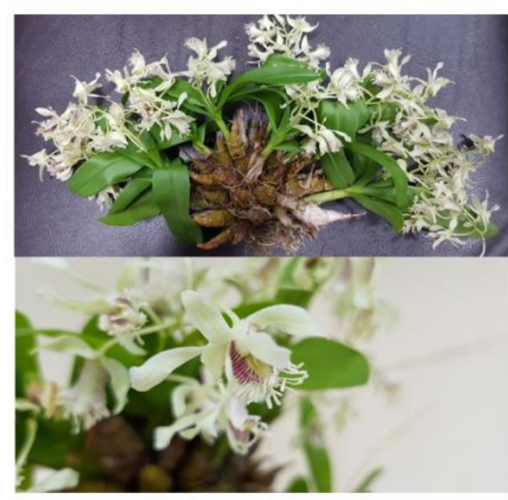

D. delacourii (b)

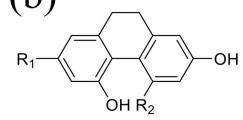

(1) $R_{1}=H ; R_{2}=O M$ (8) $\mathrm{R}_{1}=\mathrm{OMe} ; \mathrm{R}_{2}=\mathrm{H}$

(8) $\mathrm{R}_{1}=\mathrm{OM}_{2}=\mathrm{R}$

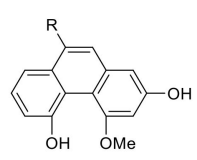

(4) $\mathrm{R}=\mathrm{H}$ (5) $\mathrm{R}=\mathrm{OCH}_{3}$

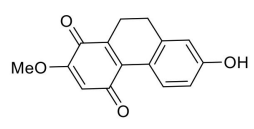

(2)

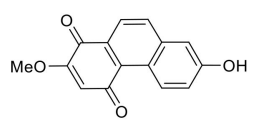

(3)

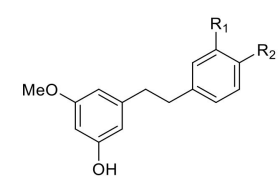

(6) $\mathrm{R}_{1}=\mathrm{OMe} ; \mathrm{R}_{2}=\mathrm{OH}$ (7) $\mathrm{R}_{1}=\mathrm{OH} ; \mathrm{R}_{2}=\mathrm{H}$
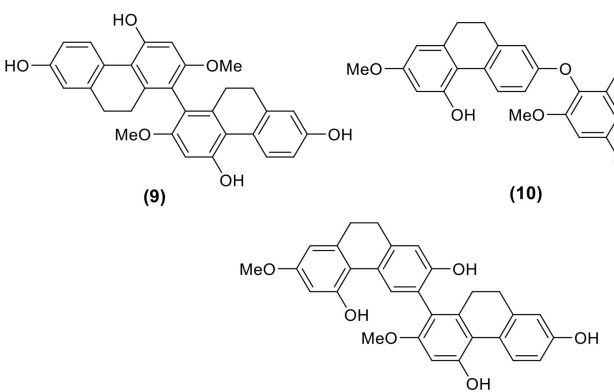

(10)

(11)

Figure 1. (a) Dendrobium delacourii. (b) The structures of isolated compounds (1-11).

\section{Results and Discussion}

\subsection{Structure Determination}

A $\mathrm{MeOH}$ extract of $D$. delacourii was separated by solvent partition to give ethyl acetate, butanol, and aqueous extracts. These extracts were evaluated for their inhibition of the $\alpha$-glucosidase enzyme and adipocyte differentiation of 3T3-L1 cells. Only the EtOAc extract showed potent inhibition of $\alpha$-glucosidase $(85.5 \%$ inhibition at $100 \mu \mathrm{g} / \mathrm{mL})$ and an anti-adipogenic effect ( $49 \%$ inhibition at $5 \mu \mathrm{g} / \mathrm{mL}$ ). Therefore, the EtOAc extract was selected for further phytochemical investigation. Chromatographic separation of the EtOAc extract resulted in the isolation of 11 compounds. The structures of isolated compounds were characterized through analysis of their spectroscopic data and in comparison with previous reported values and were identified as hircinol (1) [29], ephemeranthoquinone (2) [30], densifloral B (3) [31], moscatin (4) [32], 4,9-dimethoxy-2,5-phenanthrenediol (5) [33], gigantol (6) [34], batatasin III (7) [35], lusianthridin (8) [36], 4, 4',7,7'-tetrahydroxy-2,2'dimethoxy-9, $9^{\prime}, 10,10^{\prime}$-tetrahydro-1,1'-biphenanthrene (9) [36], phoyunnanin E (10) [36], and phoyunnanin C (11) [37] (Figure 1b).

\section{2. $\alpha$-Glucosidase Inhibitory Activity}

All the isolated compounds (1-11) were evaluated for their $\alpha$-glucosidase inhibitory activity. In this study, each compound was initially tested at $100 \mu \mathrm{g} / \mathrm{mL}$. An $\mathrm{IC}_{50}$ was determined if the compound showed more than $50 \%$ inhibition of the enzyme. The results are summarized in Table 1. Moscatin (4), gigantol (6), and lusianthridin (8) showed moderate $\alpha$-glucosidase inhibition, having $\mathrm{IC}_{50}$ values of $390.1 \pm 9.8 \mu \mathrm{M}, 191.3 \pm 6.8 \mu \mathrm{M}$, and $195.4 \pm 9.6 \mu \mathrm{M}$, respectively.

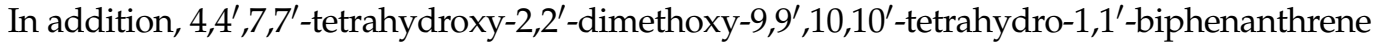
(9), phoyunnanin $\mathrm{E}$ (10), and phoyunnanin C (11) showed stronger $\alpha$-glucosidase inhibitory activities, with $\mathrm{IC}_{50}$ values of $18.4 \pm 3.4 \mu \mathrm{M}, 8.9 \pm 0.8 \mu \mathrm{M}$, and $12.6 \pm 0.9 \mu \mathrm{M}$, respectively, as compared with the positive control acarbose ( $\mathrm{IC}_{50} 514.4 \pm 9.2 \mu \mathrm{M}$ ). It can be observed herein that the dimeric phenanthrene derivatives $\mathbf{9}, \mathbf{1 0}$, and $\mathbf{1 1}$ were more potent than the monomers 4 and 8 . 
Table 1. $\alpha$-Glucosidase inhibitory activity of compounds $\mathbf{1 - 1 1}$ from the EtOAc extract.

\begin{tabular}{cc}
\hline Compounds & IC $_{\mathbf{5 0}}(\boldsymbol{\mu M})$ \\
\hline Hircinol (1) & NA \\
Ephemeranthoquinone (2) & NA \\
Densifloral B (3) & NA \\
Moscatin (4) & $390.1 \pm 9.8$ \\
Gigantol (6) & NA \\
Ba-Dimethoxy-2,5-phenanthrenediol (5) & $191.3 \pm 6.8$ \\
Lusianthridin (8) & NA \\
4, (7) $, 7,7^{\prime}$-Tetrahydroxy-2,2'-dimethoxy-9,9',10,10' & $195.4 \pm 9.6$ \\
-tetrahydro-1,1'-biphenanthrene (9) & $18.4 \pm 3.4$ \\
Phoyunnanin E (10) & $8.9 \pm 0.8$ \\
Phoyunnanin C (11) & $12.6 \pm 0.9$ \\
Acarbose & $514.4 \pm 9.2$ \\
\hline
\end{tabular}

$\mathrm{NA}=$ no inhibitory activity.

For further investigation of the mechanism of enzyme inhibition, a kinetic study was carried out on the most potent compounds, phoyunnanin E (10) and phoyunnanin C (11). The experiment was performed by using Lineweaver-Burk plots of the reciprocal of velocity $(1 / \mathrm{V})$ against the reciprocal of substrate concentration (1/[S]) (Figure 2). The substrate $p$-nitrophenol- $\alpha$-D-glucopyranoside concentration was varied from 0.25 to $2.0 \mathrm{mM}$ in the absence or presence of compound 10 at $12 \mu \mathrm{M}$ and $22 \mu \mathrm{M}$ and compound 11 at $12 \mu \mathrm{M}$ and $24 \mu \mathrm{M}$. As summarized in Table 2, the different concentrations of $\mathbf{1 0}$ and $\mathbf{1 1}$ reduced the $\mathrm{V}_{\max }$ but did not affect the $\mathrm{K}_{m}$ value, indicating that $\mathbf{1 0}$ and $\mathbf{1 1}$ are non-competitive types of enzyme inhibitors. On the other hand, the drug acarbose showed an intersection of the lines on the $y$-axis, indicating a competitive type of inhibition. A secondary plot of each compound was then constructed to evaluate the inhibition constant $\left(\mathrm{K}_{i}\right)$. We found that the $\mathrm{K}_{i}$ value of acarbose $190.57 \mu \mathrm{M}$ was obtained, and both $\mathbf{1 0}\left(\mathrm{K}_{i} 5.89 \mu \mathrm{M}\right)$ and $\mathbf{1 1}\left(\mathrm{K}_{i} 5.97 \mu \mathrm{M}\right)$ showed much greater affinity to the enzyme than acarbose. Compounds $\mathbf{1 0}$ and $\mathbf{1 1}$ as non-competitive inhibitors have some benefit over competitive inhibitors according to their binding to the allosteric site of the enzyme; therefore, they do not depend on the substrate concentration [38]. Furthermore, non-competitive inhibitors demand lower concentrations than competitive inhibitors to generate the same result [39].

Table 2. Kinetic parameters of $\alpha$-glucosidase inhibition in the presence of phoyunnanin E (10) and phoyunnanin C (11).

\begin{tabular}{ccccc}
\hline Inhibitors & Dose $(\mu \mathbf{M})$ & $\mathbf{V}_{\text {max }} \boldsymbol{\Delta} \mathbf{O O D} / \mathbf{m i n}$ & $\mathbf{K}_{m}(\mathbf{m M})$ & $\mathbf{K}_{\boldsymbol{i}}(\boldsymbol{\mu M})$ \\
\hline None & - & 0.10 & 1.22 & \\
$\mathbf{1 0}$ & 22 & 0.024 & 1.22 & 5.89 \\
& 12 & 0.049 & 1.21 & 5.97 \\
$\mathbf{1 1}$ & 24 & 0.023 & 1.21 & 190.57 \\
& 12 & 0.049 & 1.21 & \\
\hline
\end{tabular}

$\mathrm{V}_{\max }$, maximum rate of velocity; $\mathrm{K}_{m}$, Michaelis constant; $\mathrm{K}_{i}$, inhibitor constant. 
(a)

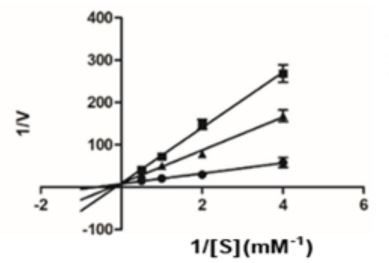

(b)

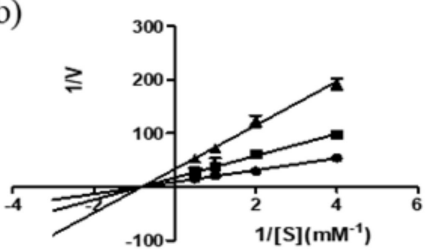

(c)

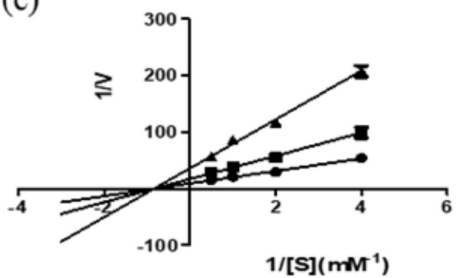

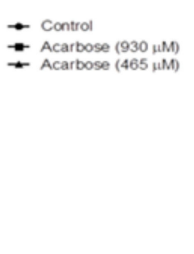
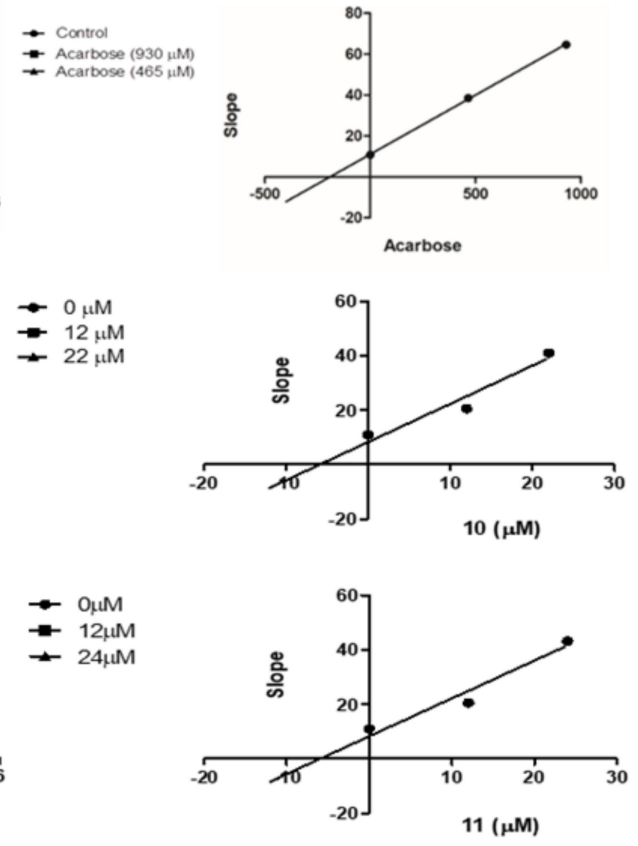

Figure 2. Lineweaver-Burk plots of (a) acarbose, (b) phoyunnanin E (10), and (c) phoyunnanin C (11). The secondary plot of each compound is on the right.

\subsection{Anti-Adipogenic Activity}

2.3.1. Ethyl Acetate Extracts from D. delacourii Attenuate Lipid Accumulation in Differentiated Adipocytes

To investigate their anti-adipogenic effect, the cytotoxic profile of $D$. delacourii extracts in preadipocytes was determined using MTT (methyl-thiazolyl-diphenyl-tetrazolium bromide) and nuclear staining assays. After culturing with $5 \mu \mathrm{g} / \mathrm{mL}$ of the methanolic, ethyl acetate, or butanolic extracts for $48 \mathrm{~h}$, there were no significant alterations in the viability percentage observed via MTT assay in mouse embryonic preadipocyte 3T3-L1 cells (Figure 3a), compared with the untreated control. It is worth noting that treatment with all extracts at $10-20 \mu \mathrm{g} / \mathrm{mL}$ reduced viability in 3T3-L1 cells to lower than $90 \%$ (data not shown). Figure $3 \mathrm{~b}$ depicts neither apoptosis nor necrosis, which were respectively observed as bright blue fluorescence of Hoechst 33342 and propidium iodide red fluorescence in all treated 3T3-L1 cells. Thus, the extracts at $5 \mu \mathrm{g} / \mathrm{mL}$, which were considered as non-toxic concentration, were chosen for the investigation of anti-adipogenic activity. Notably, treatment with oxyresveratrol (positive control), an anti-adipogenic natural compound, at $20 \mu \mathrm{M}$ for $48 \mathrm{~h}$ also caused no change in cell viability percentage and cell death in preadipocyte 3T3-L1 cells.

For determination of their anti-adipogenic effect, preadipocyte 3T3-L1 cells were incubated with the differentiation medium with or without $D$. delacourii extracts, as mentioned in Materials and Methods. After the differentiation period was complete, the accumulated intracellular lipid droplets were analyzed by oil red O staining. As shown in Figure 3c, the lower level of oil red O percentage was indicated in 3T3-L1 cells cultured either with $5 \mu \mathrm{g} / \mathrm{mL}$ methanolic extract or $5 \mu \mathrm{g} / \mathrm{mL}$ ethyl acetate extract, compared with the control group. Meanwhile the significant decrease in oil red $\mathrm{O}$ staining percentage was not demonstrated in the treatment of the butanolic extract. A comparable inhibition of adipocyte differentiation between the methanolic extract, the ethyl acetate extract, and oxyresveratrol $(20 \mu \mathrm{M})$ was evidenced with not only the reduction in the oil red O percentage but also the diminution of cellular lipid droplets presented in differentiated 3T3-L1 cells stained with oil red O (Figure 3d). Taken together, the ethyl acetate extract that indicated anti-adipogenic potential was selected for further investigation. 
(a)

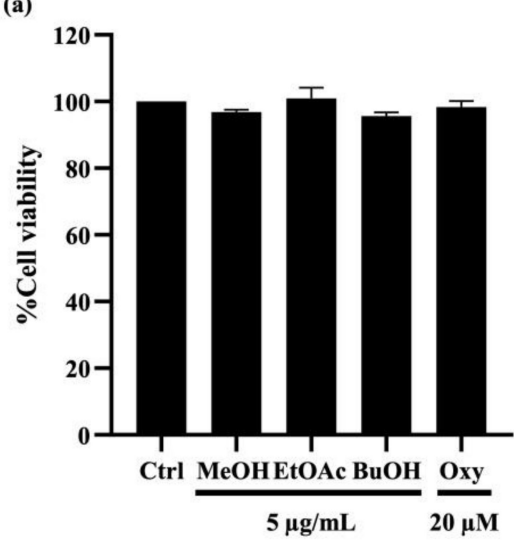

(b)

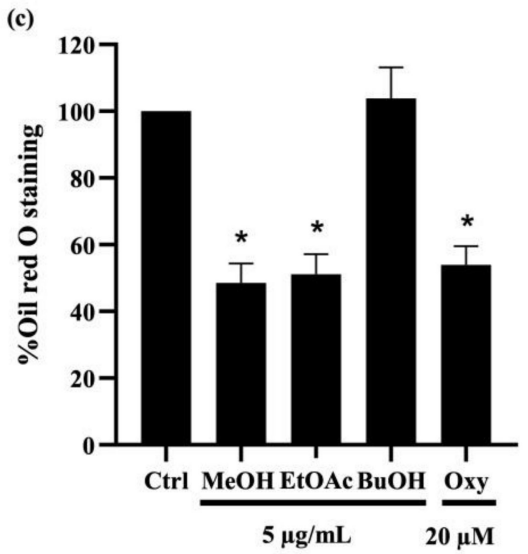

(d)
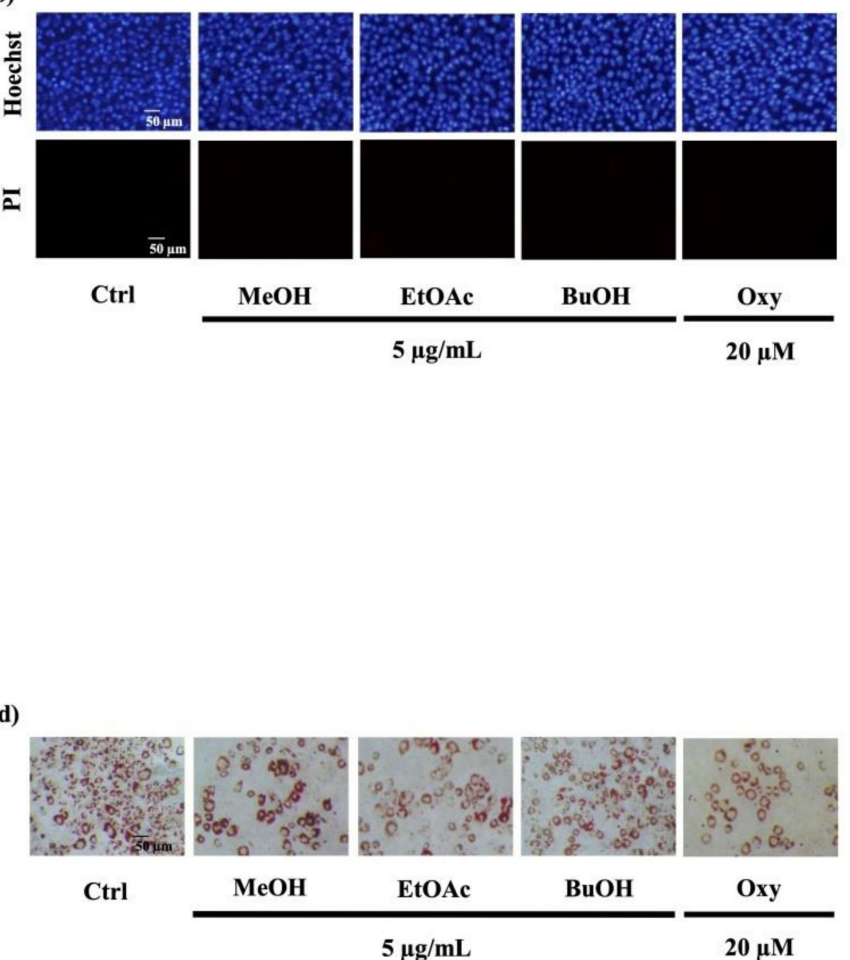

Figure 3. Effect of extracts from Dendrobium delacourii on cell viability and intracellular lipid accumulation during adipocyte differentiation. (a) MTT viability assay revealed no alteration of cell viability percentage in preadipocyte 3T3-L1 cells cultured with $5 \mu \mathrm{g} / \mathrm{mL}$ of methanolic extract $(\mathrm{MeOH})$, ethyl acetate extract (EtOAc), or butanolic extract $(\mathrm{BuOH})$ from $D$. delacourii for $48 \mathrm{~h}$. (b) Treatment with all D. delacourii extracts for $48 \mathrm{~h}$ did not cause apoptosis or necrosis cell death detected via costaining of Hoechst33342/propidium iodide (PI) in 3T3-L1 cells. The suppression of lipid accumulation during adipogenesis in preadipocyte 3T3-L1 cells incubated with $5 \mu \mathrm{g} / \mathrm{mL} \mathrm{MeOH}, 5 \mu \mathrm{g} / \mathrm{mL}$ EtOAc or $20 \mu \mathrm{M}$ oxyresveratrol (Oxy) as a positive control was evidenced with (c) lower oil red $\mathrm{O}$ staining percentage and (d) lower amount of lipid droplets containing cells stained by oil red O compared with untreated control (Ctrl) group. Data are presented as means \pm SD from three independent experiments. ${ }^{*} p<0.05$ versus non-treated control cells.

\subsubsection{Screening for Anti-Adipogenic Activity of Compounds (1-11)}

According to previous report about anti-adipogenic activity of phenolic compound, batatasin I, at $20 \mu \mathrm{M}$ [40], the suppressive effect of compounds (1-11) isolated from ethyl acetate extract of $D$. delacourii at the same concentration $(20 \mu \mathrm{M})$ was preliminarily demonstrated by the remarkable reduction in both oil red $\mathrm{O}$ staining percentage (Figure $4 \mathrm{a}$ ) and oil red O staining cells (Figure 4b) in differentiated 3T3-L1 cells. Although ephemeranthoquinone (2) and densifloral B (3) showed the highest anti-adipogenic activity among various isolates as well as positive control (oxyresveratrol), with approximately $64.7 \%$ and $65.2 \%$ reduction in oil red $\mathrm{O}$ staining, respectively, compound 2 at $20 \mu \mathrm{M}$ significantly decreased viability in 3T3-L1 cells (data not shown). Therefore, compound 3, which caused no cytotoxicity in 3T3-L1 cells, was selected to further investigate the related anti-adipogenic mechanisms. 
(b)
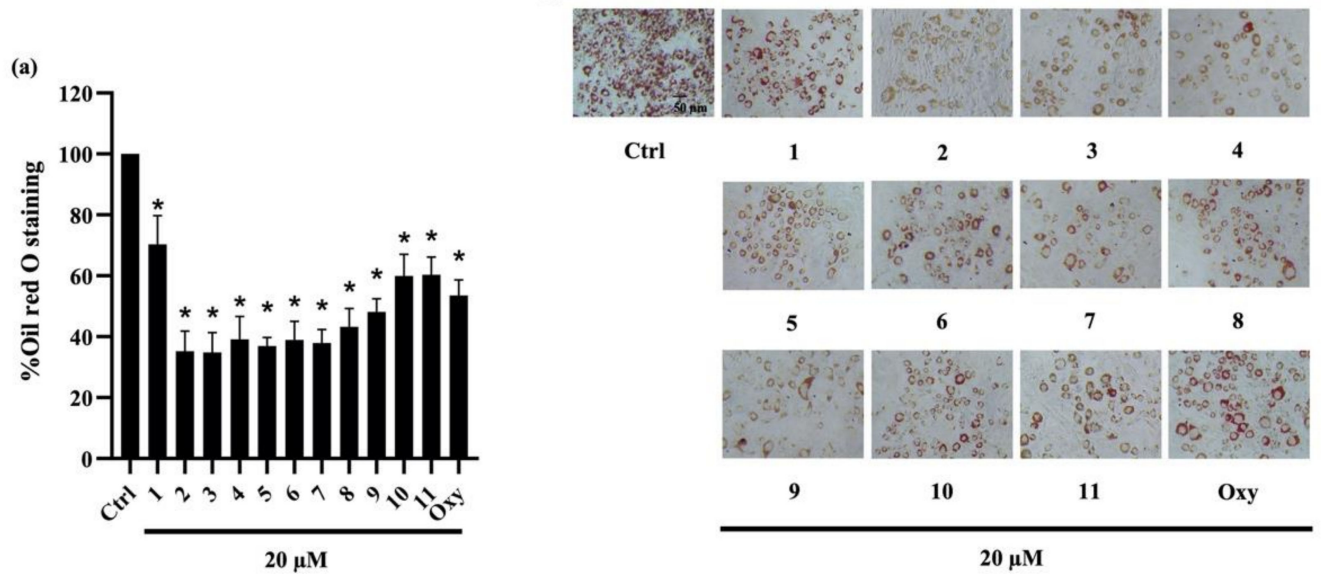

(c)

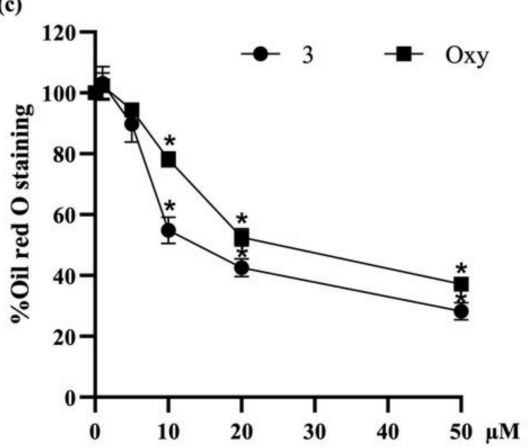

(d)

\begin{tabular}{|c|c|}
\hline Compound & IC50 \\
\hline 3 & $14.8 \pm 1.6 \mu \mathrm{M}$ \\
\hline Oxy & $21.1 \pm 1.5 \mu \mathrm{M}$ \\
\hline
\end{tabular}
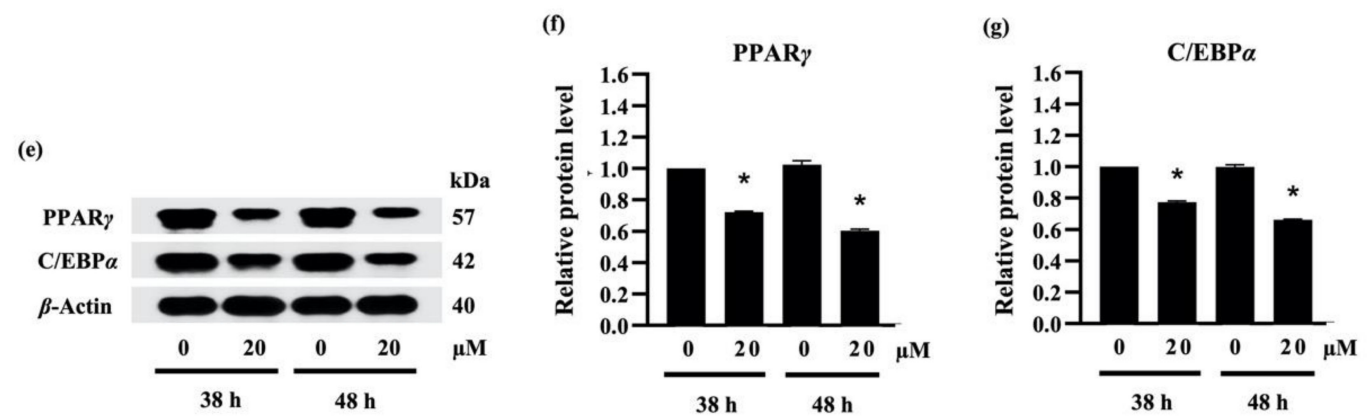

Figure 4. The effect of compounds (1-11) from Dendrobium delacourii on lipid accumulation in differentiated adipocyte was indicated with (a) the percentage of oil red $\mathrm{O}$ staining and (b) the accumulation of lipid droplets detected by oil red $\mathrm{O}$ staining. In comparison with a positive control, oxyresveratrol (Oxy), (c) dose-response relationship and (d) half-maximum inhibitory concentration $\left(\mathrm{IC}_{50}\right)$ demonstrated the more potent anti-adipogenic activity of compound 3 in 3T3-L1 cells. (e) Immunoblot analysis revealed the decreased protein levels of key lipid transcriptional regulators in 3T3-L1 cells cultured with $20 \mu \mathrm{M}$ compound 3 for both early $(38 \mathrm{~h})$ and late $(48 \mathrm{~h})$ time points. The significant reduction in (f) PPAR $\gamma$ and (g) C/EBP $\alpha$ presented early in preadipocyte 3T3-L1 cells after the incubation with $20 \mu \mathrm{M}$ compound 3 for $38 \mathrm{~h}$ in comparison with the no treatment control (Ctrl) at the same time point. $\beta$-actin was used as an internal control. Data are presented as means \pm SD from three independent experiments. ${ }^{*} p<0.05$ versus non-treated control cells at the same time point.

To compare the potency with another natural compound, preadipocyte 3T3-L1 cells were cultured with differentiation medium containing either various concentrations $(0-50 \mu \mathrm{M})$ of compound 3 or oxyresveratrol. Figure $4 \mathrm{c}$ presents the relationship between concentration and oil red $\mathrm{O}$ staining percentage in response to compound 3 and oxyresveratrol treatment. The results indicate that compound 3 and oxyresveratrol clearly restrained the adipocyte 
differentiation in 3T3-L1 cells in a dose-dependent manner. In addition, the effect of a $50 \%$ inhibitory concentration $\left(\mathrm{IC}_{50}\right)$ of compound 3 and oxyresveratrol on adipocyte differentiation was about $14.8 \pm 1.6 \mu \mathrm{M}$ and $21.1 \pm 1.5 \mu \mathrm{M}$, respectively (Figure $4 \mathrm{~d}$ ). According to $\mathrm{IC}_{50}$ data, compound 3 showed higher potency in anti-adipogenesis compared with oxyresveratrol.

\subsubsection{Densifloral B (3) Suppresses Adipocyte Differentiation-Related Proteins}

Adipogenesis involves a network of transcription factors that contribute to adipocyte differentiation and lipid accumulation [41]. Although the adipogenic gene CCAAT-enhancerbinding protein beta $(\mathrm{C} / \mathrm{EBP} \beta)$ is expressed soon after exposure to the adipogenic inducers, the upregulation of PPAR $\gamma$ and $\mathrm{C} / \mathrm{EBP} \alpha$ is acquired after $36-48 \mathrm{~h}$ of the induction [42]. In this regard, the translational level of PPAR $\gamma$ and C/EBP $\alpha$ was examined to elucidate the anti-adipogenic mechanism in preadipocyte 3T3-L1 cells cultured with $20 \mu \mathrm{M}$ densifloral B (3) at both early $(38 \mathrm{~h})$ and late $(48 \mathrm{~h})$ stage. Western blot analysis indicated the prolong expression of PPAR $\gamma$ and C/EBP $\alpha$, the adipogenic transcription factors, in 3T3-L1 cells from early until late stage of adipogenic process. Moreover, the expression level of PPAR $\gamma$ and $\mathrm{C} / \mathrm{EBP} \alpha$ was restrained in densifloral B-treated 3T3-L1 cells compared with untreated control cells (Figure 4e). Interestingly, the diminution in PPAR $\gamma$ and C/EBP $\alpha$ relative protein levels, which was promptly detected at $38 \mathrm{~h}$, was sustained until $48 \mathrm{~h}$ of adipocyte differentiation in the presence of $20 \mu \mathrm{M}$ densifloral B (Figure $4 \mathrm{f}, \mathrm{g}$, respectively).

Recent reports indicate that the downregulation of PPAR $\gamma$ and C/EBP $\alpha$ are correlated with the activation of AMPK $\alpha / \beta$ and ACC [43]. As presented in Figure 5a, treatment with $20 \mu \mathrm{M}$ densifloral B (3) upregulated the phosphorylated form of AMPK $\alpha$ (p-AMPK $\alpha$ ), AMPK $\beta 1$ (p-AMPK $\beta 1$ ), and ACC (p-ACC) in 3T3-L1 cells at both $38 \mathrm{~h}$ and $48 \mathrm{~h}$ of the differentiation period. The increased expression level of p-ACC/ACC (Figure $5 b$ ), p$\mathrm{AMPK} \alpha / \mathrm{AMPK} \alpha$ (Figure 5c), and p-AMPK $\beta 1 / \mathrm{AMPK} \beta 1 / 2$ (Figure 5f) was correlated with suppression of PPAR $\gamma$ and C/EBP $\alpha$ protein expression (Figure 4e) as well as lipid accumulation in differentiated 3T3-L1 cells (Figure 4a). The results presented in this study correspond with the evidence of the stimulation of AMPK and ACC protein being associated with the inhibition of 3T3-L1 adipocyte differentiation [44]. Interestingly, the densifloral B (3) also suppressed the activated Akt (p-Akt), an upstream regulator of the AMPK-ACC signal [45] to reduce the adipocyte formation (Figure 5d).

Due to the expression of adipogenic transcription factors also modulated via Akt/ GSK3 $\beta$ [46-48], the alteration of the p-GSK3 $\beta /$ GSK3 $\beta$ level was additionally examined in densifloral B-treated 3T3-L1 cells. The phosphorylation by p-Akt results in the inactivation of the GSK3 $\beta$ degradation complex following the initiation of targeted gene expression [49]. Surprisingly, the presence of $20 \mu \mathrm{M}$ densifloral B (3) in differentiation medium significantly lessened p-GSK3 $\beta /$ GSK3 $\beta$ expression level in preadipocyte 3T3-L1 cells at 38-48 h of differentiation time (Figure 5e). Taken together, the present results suggest that densifloral B (3) isolated from $D$. delacourii might inhibit adipocyte differentiation via suppression of the Akt-mediating GSK3 $\beta$ and AMPK-ACC signals (Figure 6). 
(a)

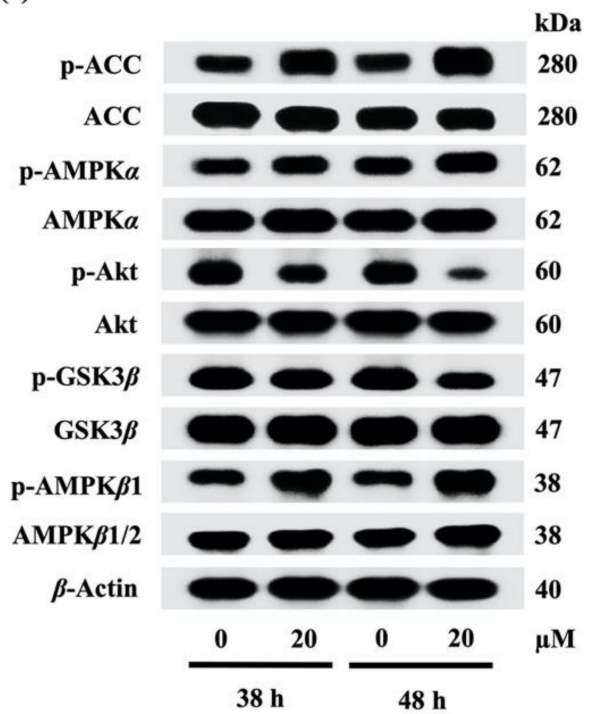

(b)

(c)

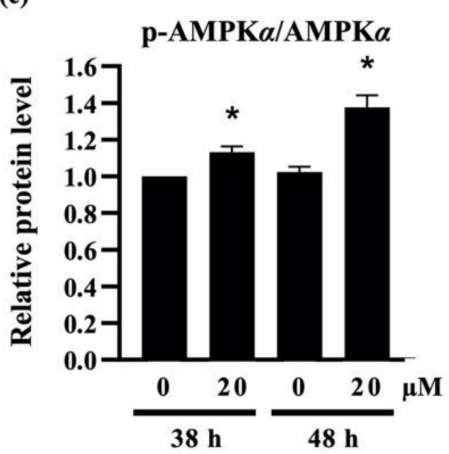

(d)

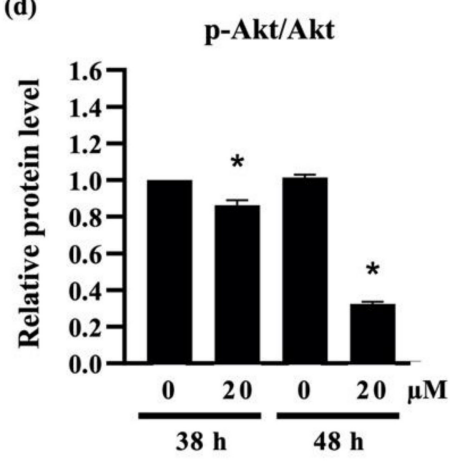

(e)

p-GSK $\boldsymbol{\beta} /$ GSK $\boldsymbol{\beta}$
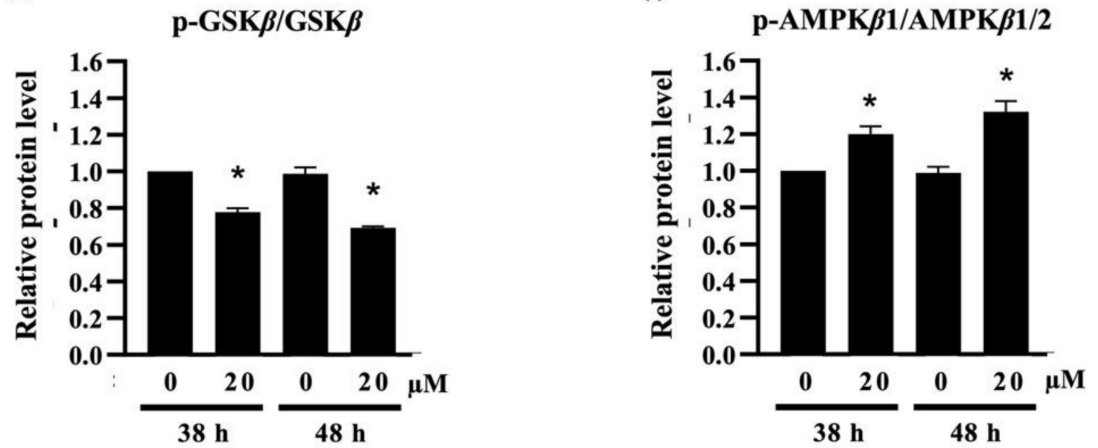

Figure 5. Effect of densifloral B (3) on adipocyte differentiation via Akt-related pathways (a) The alteration of adipogenesis-related proteins was determined in preadipocyte 3T3-L1 cells after culture with differentiation medium containing 0-20 $\mu \mathrm{M}$ densifloral B for 38-48 $\mathrm{h}$ via Western blotting. The upregulated levels of (b) p-ACC/ACC, (c) p-AMPK $\alpha / \mathrm{AMPK} \alpha$, and (f) p-AMPK $\beta 1 / \mathrm{AMPK} \beta 1 / 2$, as well as the reduction in (d) pAkt/Akt and (e) p-GSK3 $\beta /$ GSK3 $\beta$, were obviously presented in densifloral B-treated 3T3-L1 cells. $\beta$-actin served as an internal control. Data are presented as means \pm SD from three independent experiments. ${ }^{*} p<0.05$ versus non-treated control cells at the same time point. 


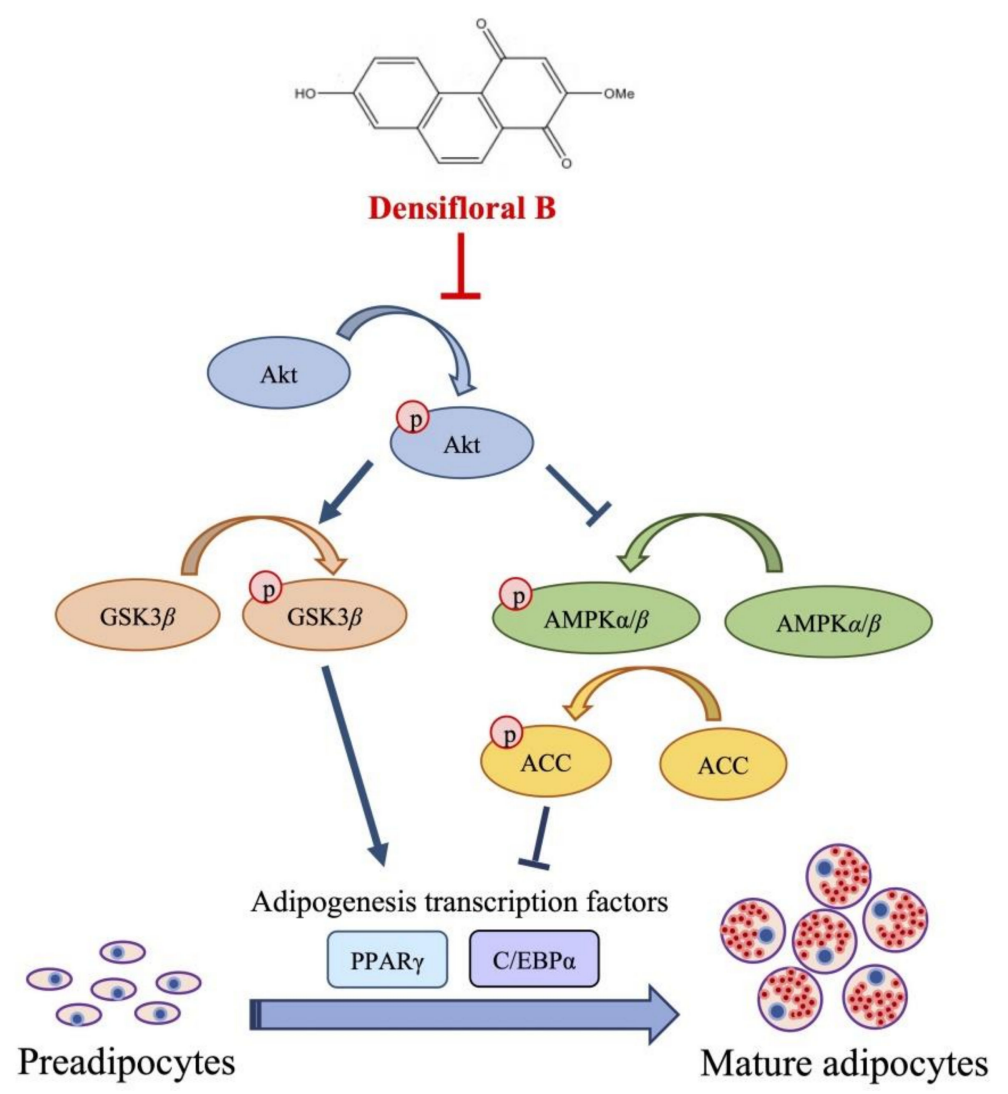

Figure 6. Proposed mechanism of densifloral B (3) on inhibition of adipogenesis via modulating Aktrelated pathways. Activated Akt (p-Akt) mediates adipocyte differentiation through upregulation of $\mathrm{p}-\mathrm{GSK} 3 \beta$ and suppression of AMPK-ACC signal that both trigger the expression of adipogenic transcription factors PPAR $\gamma$ and $\mathrm{C} / \mathrm{EBP} \alpha$. Therefore, the downregulation of $\mathrm{p}$-Akt moderated by densifloral B (3), as a consequence of the restraint of $\mathrm{p}-\mathrm{GSK} 3 \beta$ and stimulated AMPK-ACC cascades, effectively inhibits the differentiation of preadipocytes into mature adipocytes.

\section{Materials and Methods}

\subsection{General Experimental Procedures}

Mass spectra were recorded on a Bruker micro TOF mass spectrometer (ESI-MS). NMR spectra were recorded on a Bruker Avance DPX-300FT-NMR spectrometer or a Bruker Avance III HD 500 NMR spectrometer. Vacuum-liquid column chromatography (VLC) and column chromatography (CC) were performed on silica gel 60 (Merck, Kieselgel 60, 70-320 mesh), silica gel 60 (Merck, Kieselgel 60, 230-400 mesh) (Darmstadt, Germany), and Sephadex LH-20 (25-100 $\mu \mathrm{m}$, Pharmacia Fine Chemical Co. Ltd.) (Piscataway, NJ, USA). Acarbose was purchased from Fluka Chemical (Buchs, Switzerland). Mouse embryonic preadipocyte 3T3-L1 cells were acquired from the American Type Culture Collection (ATCC, Manassas, VA, USA). Dulbecco's modified Eagle medium (DMEM), fetal bovine serum (FBS), penicillin/streptomycin, and L-glutamine were obtained from Gibco (Gaithersburg, MA, USA). Yeast alpha-glucosidase enzyme, $p$-nitrophenol- $\alpha$-D-glucopyranoside, isobutylmethylxanthine, dexamethasone, MTT (methyl-thiazolyl-diphenyl-tetrazolium bromide), Hoechst33342, propidium iodide, dimethylsulfoxide (DMSO), and oil red $\mathrm{O}$ were purchased from Sigma-Aldrich (St. Louis, MO, USA). Insulin was obtained from Himedia (Mumbai, India). The radio-immunoprecipitation assay (RIPA) buffer, chemiluminescent substrates, and the bicinchoninic acid (BCA) protein assay kit were from Thermo Scientific (Rockford, IL, USA), and the nitrocellulose membranes were from Bio-Rad Laboratories (Hercules, CA, USA). All primary and secondary antibodies were purchased from Cell Signaling Technology (Danvers, MA, USA). Oxyresveratrol was provided by Prof. Kittisak Likhitwitayawuid. 


\subsection{Plant Material}

The whole plant of Dendrobium delacourii was purchased from a Chatuchak market in May 2018. Plant identification was performed by Dr. Boonchoo Sritularak. A voucher specimen (BS-Ddela-052561) was deposited at the Department of Pharmacognosy and Pharmaceutical Botany, Faculty of Pharmaceutical Sciences, Chulalongkorn University.

\subsection{Extraction and Isolation}

The dried powder of whole plant $D$. delacourii $(3.5 \mathrm{~kg})$ was macerated with $\mathrm{MeOH}$ $(4 \times 15 \mathrm{~L})$, and a methanolic extract $(300.6 \mathrm{~g})$ was obtained. This extract was dissolved in water and then partitioned with ethyl acetate (EtOAc) and butanol to give an EtOAc extract (159.7 g), a butanol extract (98.2 g), and an aqueous extract (42.1 g), respectively, after evaporation of the solvent. The EtOAc extract exhibited $85.5 \%$ inhibition of $\alpha$-glucosidase enzyme at $100 \mu \mathrm{g} / \mathrm{mL}$ and also showed $49.0 \%$ inhibition of adipocyte differentiation of 3T3-L1 cells at $5 \mu \mathrm{g} / \mathrm{mL}$, whereas the other extracts were devoid of both activities. Therefore, the EtOAc extract was subjected to further investigation.

The EtOAc extract was separated by vacuum liquid chromatography (silica gel, acetone-hexane, gradient) to give five fractions (A-E). Fraction D (54.2 g) was fractionated on a silica gel column (acetone-hexane, gradient) to give four fractions (DA-DD). Fraction DB (5.4 g) was separated by Sephadex LH-20 (methanol) to yield six fractions (DBA-DBF). Fraction DBB (612.0 mg) was subjected to column chromatography (CC) (silica gel, acetonehexane, gradient), and then the pure compounds hircinol (1) (11.4 mg) and ephemeranthoquinone (2) (6.4 mg) were obtained. Densifloral B (3) (7.9 mg), moscatin (4) (17.1 mg), and 4,9-dimethoxy-2,5-pheneanthrenediol (5) (3.6 mg) were obtained from fractions DBD, DBE, and DBF after purification on a silica gel column (acetone-hexane, gradient). Fraction DC (6.1 g) was separated by Sephadex LH-20 (methanol) to yield four fractions (DCADCD). The separation of fraction DCA (1.2 g) by CC (silica gel, acetone-hexane, gradient) resulted in gigantol (6) $(166.5 \mathrm{mg})$. Fraction DCB (170.9 $\mathrm{mg})$ was separated on a silica gel column (EtOAc- $\mathrm{CH}_{2} \mathrm{Cl}_{2}$, gradient) to yield batatasin III (7). Fraction DCD (428.0 mg) was isolated by a silica gel column (acetone-hexane, gradient) to give lusianthridin (8). Fraction DD (6.7 g) was separated by Sephadex LH-20 (methanol) to yield three fractions (DDA-DDC). Quantities of 4,4',7,7'-tetrahydroxy-2,2'-dimethoxy-9,9',10,10' -tetrahydro-1,1' biphenanthrene (9) $(4.7 \mathrm{mg})$ and phoyunnanin $\mathrm{E}(\mathbf{1 0})(7.0 \mathrm{mg})$ were obtained from fraction DDB, and phoyunnanin C (11) $(6.8 \mathrm{mg})$ was obtained from fraction DDC after separation in a silica gel column (methanol- $\mathrm{CH}_{2} \mathrm{Cl}_{2}$, gradient).

Hircinol (1): yellow amorphous solid; HR-ESI-MS: $m / z 243.1059[\mathrm{M}+\mathrm{H}]^{+}$calcd. for $\mathrm{C}_{15} \mathrm{H}_{15} \mathrm{O}_{3}, 243.1021$, suggesting $\mathrm{C}_{15} \mathrm{H}_{14} \mathrm{O}_{3}$. ${ }^{1} \mathrm{H}$ NMR (500 MHz, acetone- $\left.d_{6}\right) \delta: 2.59(4 \mathrm{H}, \mathrm{m}$, $\mathrm{H}_{2}-9$ and $\left.\mathrm{H}_{2}-10\right), 3.97(3 \mathrm{H}, \mathrm{s}, 4-\mathrm{MeO}), 6.56(1 \mathrm{H}, \mathrm{d}, J=2.5 \mathrm{~Hz}, \mathrm{H}-1), 6.60(1 \mathrm{H}, \mathrm{d}, J=2.5 \mathrm{~Hz}$, $\mathrm{H}-3), 6.80(2 \mathrm{H}, \mathrm{d}, J=8.0 \mathrm{~Hz}, \mathrm{H}-6, \mathrm{H}-8), 7.06(1 \mathrm{H}, \mathrm{t}, J=8.0 \mathrm{~Hz}, \mathrm{H}-7) ;{ }^{13} \mathrm{C} \mathrm{NMR}(125 \mathrm{MHz}$, acetone- $\left.d_{6}\right) \delta: 31.6$ (C-10), 31.8 (C-9), 57.2 (4-MeO), 99.8 (C-3), 109.8 (C-1), 114.6 (C-4b), 118.2 (C-6), 120.1 (C-8), 128.1 (C-7), 130.4 (C-4a), 141.3 (C-8a), 144.2 (C-10a), 154.7 (C-4), 156.3 (C-5), 158.5 (C-2).

Ephemeranthoquinone (2): reddish powder; HR-ESI-MS: $m / z 279.06185[\mathrm{M}+\mathrm{Na}]^{+}$ calcd. for $\mathrm{C}_{15} \mathrm{H}_{12} \mathrm{O}_{4} \mathrm{Na}, 279.06333$ suggesting $\mathrm{C}_{15} \mathrm{H}_{12} \mathrm{O}_{4} \cdot{ }^{1} \mathrm{H}$ NMR (300 MHz, acetone- $d_{6}$ )

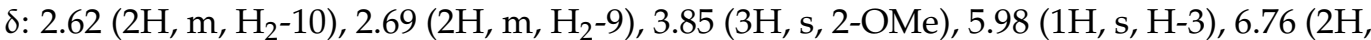
m, H-6, H-8), $7.97(1 \mathrm{H}, \mathrm{d}, J=9.3 \mathrm{~Hz}, \mathrm{H}-5) ;{ }^{13} \mathrm{C}$ NMR $\left(75 \mathrm{MHz}\right.$, acetone- $\left.d_{6}\right) \delta: 20.0(\mathrm{C}-10)$, 27.2 (C-9), 55.7 (2-OMe), 107.4 (C-3), 113.4 (C-5), 114.8 (C-8), 121.2 (C-4b), 132.0 (C-6), 136.1 (C-4a), 136.2 (C-10a), 141.5 (C-8a), 158.6 (C-2), 159.1 (C-7), 180.8 (C-1), 187.2 (C-4).

Densifloral B (3): orange powder, HR-ESIMS: $m / z 277.0473[\mathrm{M}+\mathrm{Na}]^{+}$calcd. for $\mathrm{C}_{15} \mathrm{H}_{10} \mathrm{O}_{4} \mathrm{Na}, 277.04768$ suggesting $\mathrm{C}_{15} \mathrm{H}_{10} \mathrm{O}_{4} \cdot{ }^{1} \mathrm{H}$ NMR $\left(300 \mathrm{MHz}\right.$, acetone- $\left.d_{6}\right) \delta: 3.92(3 \mathrm{H}$, s, 2-OMe), $6.20(1 \mathrm{H}, \mathrm{s}, \mathrm{H}-3), 7.31(1 \mathrm{H}, \mathrm{d}, J=2.4 \mathrm{~Hz}, \mathrm{H}-8), 7.35(1 \mathrm{H}, \mathrm{dd}, J=2.4,9.3 \mathrm{~Hz}, \mathrm{H}-6)$, $8.04\left(2 \mathrm{H}\right.$, br s, H-9 and H-10), $9.49(1 \mathrm{H}, \mathrm{d}, J=9.3 \mathrm{~Hz}, \mathrm{H}-5) ;{ }^{13} \mathrm{C}$ NMR $\left(75 \mathrm{MHz}\right.$, acetone- $\left.d_{6}\right)$ ঠ: 55.8 (2-OMe), 109.9 (C-8), 110.9 (C-3), 122.0 (C-5, C-6), 124.2 (C-4b), 127.5 (C-4a), 130.1 (C-10a), 132.3 (C-10), 134.2 (C-9), 139.4 (C-8a), 157.8 (C-7), 160.2 (C-2), 180.5 (C-1), 188.4 $(\mathrm{C}-4)$. 
Moscatin (4): brown amorphous solid, HR-ESIMS: $m / z 241.0888[\mathrm{M}+\mathrm{H}]^{+}$calcd. for $\mathrm{C}_{15} \mathrm{H}_{13} \mathrm{O}_{3}$ 241.0865, suggesting $\mathrm{C}_{15} \mathrm{H}_{12} \mathrm{O}_{3} .{ }^{1} \mathrm{H}$ NMR (500 MHz, acetone- $\left.d_{6}\right) \delta: 4.15(3 \mathrm{H}, \mathrm{s}$, 4-OMe), $6.99(1 \mathrm{H}, \mathrm{d}, J=2.5 \mathrm{~Hz}, \mathrm{H}-3), 7.07(1 \mathrm{H}, \mathrm{d}, J=2.5 \mathrm{~Hz}, \mathrm{H}-1), 7.10(1 \mathrm{H}, \mathrm{dd}, J=7.5,2.0$ Hz, H-6), 7.41 (1H, dd, J = 7.5, 2.0 Hz, H-8), $7.43(1 \mathrm{H}, \mathrm{t}, J=7.5 \mathrm{~Hz}, \mathrm{H}-7), 7.49(1 \mathrm{H}, \mathrm{d}, J=9.0$ $\mathrm{Hz} \mathrm{H}-10), 7.63(1 \mathrm{H}, \mathrm{d}, J=9.0 \mathrm{~Hz}, \mathrm{H}-9) ;{ }^{13} \mathrm{C} \mathrm{NMR}\left(125 \mathrm{MHz}\right.$, acetone- $\left.d_{6}\right) \delta: 58.6(4-\mathrm{OMe})$, 102.5 (C-3), 107.8 (C-1), 113.9 (C-4a), 116.9 (C-6), 119.8 (C-4b), 121.0 (C-8), 126.9 (C-10), 127.4 (C-7), 129.7 (C-9), 135.0 (C-8a), 137.1 (C-10a), 155.2 (C-5), 156.4 (C-2), 157.3 (C-4).

4,9-Dimethoxy-2,5-phenanthrenediol (5): brown amorphous solid. HR-ESIMS: at $m / z$ 271.1009, $[\mathrm{M}+\mathrm{H}]^{+}$calcd for $\mathrm{C}_{16} \mathrm{H}_{15} \mathrm{O}_{4} ; 271.0970$, suggesting $\mathrm{C}_{16} \mathrm{H}_{14} \mathrm{O}_{4} \cdot{ }^{1} \mathrm{H}$ NMR $(500 \mathrm{MHz}$, acetone- $\left.d_{6}\right) \delta: 4.03(3 \mathrm{H}, \mathrm{s}, 9-\mathrm{OMe}), 4.11(3 \mathrm{H}, \mathrm{s}, 4-\mathrm{OMe}), 6.81(1 \mathrm{H}, \mathrm{d}, J=2.5 \mathrm{~Hz}, \mathrm{H}-3), 6.92$ $(1 \mathrm{H}, \mathrm{s}, \mathrm{H}-10), 6.99(1 \mathrm{H}, \mathrm{d}, J=2.5 \mathrm{~Hz}, \mathrm{H}-1), 7.12(1 \mathrm{H}, \mathrm{dd}, J=1.5,7.5 \mathrm{~Hz}, \mathrm{H}-6), 7.43(1 \mathrm{H}, \mathrm{t}$, $J=7.5 \mathrm{~Hz}, \mathrm{H}-7), 7.85(1 \mathrm{H}, \mathrm{dd}, J=1.5,7.5 \mathrm{~Hz}, \mathrm{H}-8), 8.82(1 \mathrm{H}, \mathrm{s}, 2-\mathrm{OH}), 9.43(1 \mathrm{H}, \mathrm{s}, 5-\mathrm{OH})$; ${ }^{13} \mathrm{C}$ NMR (125 MHz, acetone- $\left.d_{6}\right) \delta: 55.9$ (9-OMe), 58.5 (4-OMe), 100.3 (C-3), 102.8 (C-10), 106.9 (C-1), 110.0 (C-4a), 114.3 (C-8), 117.6 (C-6), 120.9 (C-4b), 127.9 (C-7), 129.2 (C-8a), 137.9 (C-10a), 154.9 (C-9), 155.2 (C-5), 156.3 (C-4), 157.5 (C-2).

Gigantol (6): brown amorphous solid. HR-ESIMS: at $m / z$ 297.1102, [M + Na $]^{+}$calculated for $\mathrm{C}_{16} \mathrm{H}_{18} \mathrm{O}_{4} \mathrm{Na}$; 297.1102, suggesting $\mathrm{C}_{16} \mathrm{H}_{18} \mathrm{O}_{4} \cdot{ }^{1} \mathrm{H}$ NMR (500 MHz, acetone- $\left.d_{6}\right) \delta$ : $2.79\left(4 \mathrm{H}, \mathrm{m}, \mathrm{H}_{2}-\alpha, \mathrm{H}_{2}-\alpha^{\prime}\right), 3.69$ (3H, s, 3-OMe), 3.77 (3H, s, 3'-OMe), $6.25(1 \mathrm{H}, \mathrm{t}, J=1.5 \mathrm{~Hz}$, H-4), $6.29(1 \mathrm{H}, \mathrm{t}, J=1.5 \mathrm{~Hz}, \mathrm{H}-6), 6.32(1 \mathrm{H}, \mathrm{t}, J=1.5 \mathrm{~Hz}, \mathrm{H}-2), 6.65(1 \mathrm{H}, \mathrm{dd}, J=8.0,2.0 \mathrm{~Hz}$, H-6 $\left.{ }^{\prime}\right), 6.73\left(1 \mathrm{H}, \mathrm{d}, J=8.0 \mathrm{~Hz}, \mathrm{H}-5^{\prime}\right), 6.79\left(1 \mathrm{H}, \mathrm{d}, J=2.0 \mathrm{~Hz}, \mathrm{H}-2^{\prime}\right) ;{ }^{13} \mathrm{C} \mathrm{NMR}(125 \mathrm{MHz}$, acetone- $\left.d_{6}\right) \delta: 37.9\left(\mathrm{C}-\alpha^{\prime}\right), 38.9(\mathrm{C}-\alpha), 55.2$ (3'-OMe), 56.1 (3-OMe), $99.7(\mathrm{C}-4), 106.3(\mathrm{C}-6)$, $108.9(\mathrm{C}-2), 112.8\left(\mathrm{C}-5^{\prime}\right), 115.5\left(\mathrm{C}-2^{\prime}\right), 121.5\left(\mathrm{C}-6^{\prime}\right), 134.1\left(\mathrm{C}-1^{\prime}\right), 145.1\left(\mathrm{C}-4^{\prime}\right), 145.4(\mathrm{C}-1), 147.9$ $\left(\mathrm{C}-3^{\prime}\right), 159.2(\mathrm{C}-3), 161.8(\mathrm{C}-5)$.

Batatasin III (7): brown amorphous solid. HR-ESIMS: at $m / z$ 267.10556, $[\mathrm{M}+\mathrm{Na}]^{+}$ calculated for $\mathrm{C}_{15} \mathrm{H}_{16} \mathrm{O}_{3} \mathrm{Na} ; 267.099715$, suggesting $\mathrm{C}_{15} \mathrm{H}_{16} \mathrm{O}_{3}$. ${ }^{1} \mathrm{H}$ NMR $(500 \mathrm{MHz}$, acetone$\left.d_{6}\right) \delta: 2.79\left(4 \mathrm{H}, \mathrm{m}, \mathrm{H}-\alpha, \mathrm{H}-\alpha^{\prime}\right), 3.70(3 \mathrm{H}, \mathrm{s}, 3-\mathrm{OMe}), 6.23(1 \mathrm{H}, \mathrm{t}, J=2.0 \mathrm{~Hz}, \mathrm{H}-4), 6.30(1 \mathrm{H}, \mathrm{t}$, $J=2.0 \mathrm{~Hz}, \mathrm{H}-2), 6.32(1 \mathrm{H}, \mathrm{br} \mathrm{t}, J=2.0 \mathrm{~Hz}, \mathrm{H}-6), 6.63\left(1 \mathrm{H}, \mathrm{m}, \mathrm{H}-4^{\prime}\right), 6.69(1 \mathrm{H}, \mathrm{br} \mathrm{d}, J=9.0 \mathrm{~Hz}$, $\left.\mathrm{H}-6^{\prime}\right), 6.71\left(1 \mathrm{H}, \mathrm{br} \mathrm{d}, J=2.4 \mathrm{~Hz}, \mathrm{H}-2^{\prime}\right), 7.07\left(1 \mathrm{H}, \mathrm{t}, J=8.0 \mathrm{~Hz}, \mathrm{H}-5^{\prime}\right) ;{ }^{13} \mathrm{C} \mathrm{NMR}(125 \mathrm{MHz}$, acetone- $\left.d_{6}\right) \delta: 38.2\left(\mathrm{C}-\alpha^{\prime}\right), 38.5(\mathrm{C}-\alpha), 55.2$ (3-OMe), $99.8(\mathrm{C}-4), 106.2(\mathrm{C}-2), 108.8(\mathrm{C}-6), 113.6$ $\left(\mathrm{C}-4^{\prime}\right), 116.2\left(\mathrm{C}-2^{\prime}\right), 120.4\left(\mathrm{C}-6^{\prime}\right), 130.0\left(\mathrm{C}-5^{\prime}\right), 144.3\left(\mathrm{C}-1^{\prime}\right), 145.0(\mathrm{C}-1), 158.2\left(\mathrm{C}-3^{\prime}\right), 159.2$ (C-3), 161.8 (C-5).

Lusianthridin (8): brown amorphous solid. HR-ESIMS: at $m / z 265.08251,[\mathrm{M}+\mathrm{Na}]^{+}$ calculated for $\mathrm{C}_{15} \mathrm{H}_{14} \mathrm{O}_{3} \mathrm{Na} ; 265.084065$, suggesting $\mathrm{C}_{15} \mathrm{H}_{14} \mathrm{O}_{3}$. ${ }^{1} \mathrm{H}$ NMR (500 MHz, acetone$\left.d_{6}\right) \delta: 2.67\left(4 \mathrm{H}, \mathrm{m}, \mathrm{H}_{2}-9\right.$ and $\left.\mathrm{H}_{2}-10\right), 3.72(3 \mathrm{H}, \mathrm{s}, 2-\mathrm{OMe}), 6.37(1 \mathrm{H}, \mathrm{d}, J=2.5 \mathrm{~Hz}, \mathrm{H}-1), 6.45$ $(1 \mathrm{H}, \mathrm{d}, J=2.5 \mathrm{~Hz}, \mathrm{H}-3), 6.73(1 \mathrm{H}, \mathrm{br} \mathrm{d}, J=7.5 \mathrm{~Hz}, \mathrm{H}-6), 6.72(1 \mathrm{H}, \mathrm{br} \mathrm{s}, \mathrm{H}-8), 8.24(1 \mathrm{H}, \mathrm{d}$ $J=7.5 \mathrm{~Hz}, \mathrm{H}-5) ;{ }^{13} \mathrm{C}$ NMR (125 MHz, acetone- $\left.d_{6}\right) \delta: 30.6$ (C-9), 31.3 (C-10), 55.2 (2-OMe), 101.5 (C-3), 105.8 (C-1), 113.4 (C-6), 115.0 (C-8), 115.7 (C-4a), 125.8 (C-4b), 129.8 (C-5), 139.7 (C-8a), 141.3 (C-10a), 155.7 (C-4), 155.8 (C-7), 159.1 (C-2).

$4,4^{\prime}, 7,7^{\prime}$-Tetrahydroxy-2,2'-dimethoxy-9,9',10,10'-tetrahydro-1,1'-biphenanthrene (9): yellow amorphous powder, HR-ESIMS: at $m / z$ 505.1630, $[\mathrm{M}+\mathrm{Na}]^{+}$calculated for $\mathrm{C}_{30} \mathrm{H}_{26} \mathrm{O}_{6} \mathrm{Na}$; 505.1627 suggesting $\mathrm{C}_{30} \mathrm{H}_{26} \mathrm{O}_{6}{ }^{1} \mathrm{H}$ NMR (300 MHz, acetone- $\left.d_{6}\right) \delta: 2.31\left(4 \mathrm{H}, \mathrm{m}, \mathrm{H}_{2}-10, \mathrm{H}_{2}-\right.$ $\left.10^{\prime}\right), 2.51\left(4 \mathrm{H}, \mathrm{m}, \mathrm{H}_{2}-9, \mathrm{H}_{2}-9^{\prime}\right), 3.60$ (6H, s, 2-OMe, 2'-OMe), 6.57 (2H, s, H-3, H-3'), $6.65(2 \mathrm{H}$, $\left.\mathrm{d}, J=2.4 \mathrm{~Hz}, \mathrm{H}-8, \mathrm{H}-8^{\prime}\right), 6.69\left(2 \mathrm{H}, \mathrm{dd}, J=8.4,2.4 \mathrm{~Hz}, \mathrm{H}-6, \mathrm{H}-6^{\prime}\right), 8.25(2 \mathrm{H}, \mathrm{d}, J=8.4 \mathrm{~Hz}, \mathrm{H}-5$, $\left.\mathrm{H}-5^{\prime}\right), 8.08\left(2 \mathrm{H}, \mathrm{s}, 7-\mathrm{OH}, 7^{\prime}-\mathrm{OH}\right), 8.41\left(2 \mathrm{H}, \mathrm{s}, 4-\mathrm{OH}, 4^{\prime}-\mathrm{OH}\right) ;{ }^{13} \mathrm{C}$ NMR $\left(75 \mathrm{MHz}\right.$, acetone- $\left.d_{6}\right)$

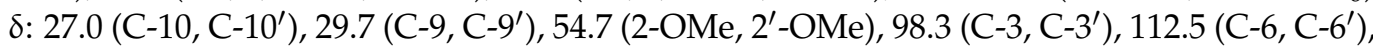
$113.8\left(\mathrm{C}-8, \mathrm{C}-8^{\prime}\right), 114.6\left(\mathrm{C}-4 \mathrm{a}, \mathrm{C}-4 \mathrm{a}^{\prime}\right), 116.5\left(\mathrm{C}-1, \mathrm{C}-1^{\prime}\right), 125.5\left(\mathrm{C}-4 \mathrm{~b}, \mathrm{C}-4 \mathrm{~b}^{\prime}\right), 129.3\left(\mathrm{C}-5, \mathrm{C}-5^{\prime}\right)$, $139.3\left(\mathrm{C}-8 \mathrm{a}, \mathrm{C}-8 \mathrm{a}^{\prime}\right), 139.7\left(\mathrm{C}-10 \mathrm{a}, \mathrm{C}-10 \mathrm{a}^{\prime}\right), 154.0\left(\mathrm{C}-4, \mathrm{C}-4^{\prime}\right), 155.1\left(\mathrm{C}-7, \mathrm{C}-7^{\prime}\right), 156.4\left(\mathrm{C}-2, \mathrm{C}^{\prime}{ }^{\prime}\right)$.

Phoyunnanin E (10): amorphous powder, HR-ESIMS: at $m / z$ 505.1628, $[\mathrm{M}+\mathrm{Na}]^{+}$ calculated for $\mathrm{C}_{30} \mathrm{H}_{26} \mathrm{O}_{6} \mathrm{Na}$; 505.1627, suggesting $\mathrm{C}_{30} \mathrm{H}_{26} \mathrm{O}_{6} \cdot{ }^{1} \mathrm{H}$ NMR (500 MHz, acetone$\left.d_{6}\right) \delta: 2.60\left(4 \mathrm{H}, \mathrm{m}, \mathrm{H}_{2}-9\right.$ and $\left.\mathrm{H}_{2}-10\right), 2.67\left(4 \mathrm{H}, \mathrm{m}, \mathrm{H}_{2}-9^{\prime}, \mathrm{H}_{2}-10^{\prime}\right), 3.71(3 \mathrm{H}, \mathrm{s}, 2-\mathrm{OMe}), 3.73$ $\left(3 \mathrm{H}, \mathrm{s}, 2^{\prime}-\mathrm{OMe}\right), 6.37\left(1 \mathrm{H}, \mathrm{d}, J=2.5 \mathrm{~Hz}, \mathrm{H}-1^{\prime}\right), 6.42\left(1 \mathrm{H}, \mathrm{d}, J=2.5 \mathrm{~Hz}, \mathrm{H}-3^{\prime}\right), 6.62(1 \mathrm{H}, \mathrm{dd}$, $\left.J=8.5,2.5 \mathrm{~Hz}, \mathrm{H}-6^{\prime}\right), 6.66(1 \mathrm{H}, \mathrm{s}, \mathrm{H}-3), 6.67\left(1 \mathrm{H}, \mathrm{d}, J=2.5 \mathrm{~Hz}, \mathrm{H}-8^{\prime}\right), 6.69(1 \mathrm{H}, \mathrm{d}, J=2.5 \mathrm{~Hz}$, $\mathrm{H}-8), 6.71(1 \mathrm{H}, \mathrm{dd}, J=2.5,9.0 \mathrm{~Hz}, \mathrm{H}-6), 8.25\left(1 \mathrm{H}, \mathrm{d}, J=8.5 \mathrm{~Hz}, \mathrm{H}-5^{\prime}\right), 8.27(1 \mathrm{H}, \mathrm{d}, J=9.0 \mathrm{~Hz}$, $\mathrm{H}-5) ;{ }^{13} \mathrm{C}$ NMR (125 MHz, acetone- $\left.d_{6}\right) \delta: 23.8$ (C-10), 30.7 (C-9', C-9), 31.3 (C-10'), 55.3 
(2'-OMe), 56.0 (2-OMe), 100.8 (C-3), $101.6\left(\mathrm{C}-3^{\prime}\right), 106.0\left(\mathrm{C}-1^{\prime}\right), 112.6\left(\mathrm{C}-6^{\prime}\right), 113.6(\mathrm{C}-6), 114.2$ $\left(\mathrm{C}-8^{\prime}\right), 115.0(\mathrm{C}-8), 115.5\left(\mathrm{C}-4 \mathrm{a}^{\prime}\right), 115.7(\mathrm{C}-4 \mathrm{a}), 125.6(\mathrm{C}-4 \mathrm{~b}), 127.6\left(\mathrm{C}-4 \mathrm{~b}^{\prime}\right), 129.8\left(\mathrm{C}-5^{\prime}\right), 130.2$

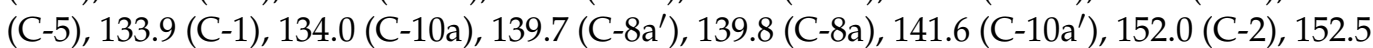
(C-4), $156.1\left(\mathrm{C}-4^{\prime}\right), 156.4(\mathrm{C}-7), 157.7\left(\mathrm{C}-7^{\prime}\right), 159.6\left(\mathrm{C}-2^{\prime}\right)$.

Phoyunnanin $C$ (11): amorphous powder, HR-ESIMS: at $m / z 505.1635,[\mathrm{M}+\mathrm{Na}]^{+}$ calculated for $\mathrm{C}_{30} \mathrm{H}_{26} \mathrm{O}_{6} \mathrm{Na}$; 505.1627, suggesting $\mathrm{C}_{30} \mathrm{H}_{26} \mathrm{O}_{6} \cdot{ }^{1} \mathrm{H}$ NMR (300 MHz, acetone$\left.d_{6}\right) \delta: 2.51\left(2 \mathrm{H}, \mathrm{m}, \mathrm{H}_{2}-10\right), 2.53\left(2 \mathrm{H}, \mathrm{m}, \mathrm{H}_{2}-9\right), 2.73\left(4 \mathrm{H}, \mathrm{m}, \mathrm{H}_{2}-9^{\prime}, \mathrm{H}_{2}-10^{\prime}\right), 3.64(3 \mathrm{H}, \mathrm{s}, 2-\mathrm{OMe})$, $3.72\left(3 \mathrm{H}, \mathrm{s}, 2^{\prime}-\mathrm{OMe}\right), 6.38\left(2 \mathrm{H}, \mathrm{br} \mathrm{s}, \mathrm{H}-1^{\prime}, \mathrm{H}-3^{\prime}\right), 6.57(1 \mathrm{H}, \mathrm{s}, \mathrm{H}-3), 6.66(1 \mathrm{H}, \mathrm{d}, J=2.7 \mathrm{~Hz}$, H-8), 6.69 (1H, dd, $J=8.4,2.7 \mathrm{~Hz}, \mathrm{H}-6), 6.76\left(1 \mathrm{H}, \mathrm{s}, \mathrm{H}-8^{\prime}\right), 8.08\left(1 \mathrm{H}, \mathrm{s}, \mathrm{H}-5^{\prime}\right), 8.23(1 \mathrm{H}, \mathrm{d}$, $J=8.4 \mathrm{~Hz}, \mathrm{H}-5) ;{ }^{13} \mathrm{C}$ NMR $\left(75 \mathrm{MHz}\right.$, acetone- $\left.d_{6}\right) \delta: 27.5(\mathrm{C}-10), 29.6\left(\mathrm{C}-9, \mathrm{C}-9^{\prime}\right), 30.7\left(\mathrm{C}-10^{\prime}\right)$, 54.4 (2-OMe), 54.8 (2'-OMe), 98.5 (C-3), 100.7 (C-3'), $105.1\left(\mathrm{C}-1^{\prime}\right), 112.5$ (C-6), 113.8 (C-8), $114.3\left(\mathrm{C}-8^{\prime}\right), 114.9(\mathrm{C}-4 \mathrm{a}), 115.1\left(\mathrm{C}-4 \mathrm{a}^{\prime}\right), 117.4(\mathrm{C}-1), 121.7\left(\mathrm{C}-6^{\prime}\right), 124.8\left(\mathrm{C}-4 \mathrm{~b}^{\prime}\right), 125.3(\mathrm{C}-4 \mathrm{~b})$, $129.3(\mathrm{C}-5), 131.7\left(\mathrm{C}-5^{\prime}\right), 137.7\left(\mathrm{C}-8 \mathrm{a}^{\prime}\right), 139.2(\mathrm{C}-8 \mathrm{a}), 140.1(\mathrm{C}-10 \mathrm{a}), 140.5\left(\mathrm{C}-10 \mathrm{a}^{\prime}\right), 152.8\left(\mathrm{C}-7^{\prime}\right)$, 154.3 (C-4), $155.1\left(\mathrm{C}-4^{\prime}\right), 155.2(\mathrm{C}-7), 156.6(\mathrm{C}-2), 158.3\left(\mathrm{C}-2^{\prime}\right)$.

\subsection{Assay for $\alpha$-Glucosidase Inhibitory Activity}

The assay was based on the inhibition in the sample of $\alpha$-glucosidase enzyme, which can release $p$-nitrophenol (PNP) from $p$-nitrophenyl- $\alpha$-D-glucoside (PNPG) by hydrolysis [48]. In this assay, acarbose was used as the positive control. For $\mathrm{IC}_{50}$ determination, twofold serial dilution was performed for each sample. Each experiment was accomplished in triplicate. Data are expressed as mean \pm SD.

The kinetic study of enzyme inhibition was analyzed by the double reciprocal Lineweaver-Burk plot (1/V versus $1 /[S])$. The experiment was carried out by performing various concentrations of substrate $p$-nitrophenol- $\alpha$-D-glucopyranoside $(0.25,0.5,1.0,2.0 \mathrm{mM})$ in the absence or presence of compound (10) (12 and $22 \mu \mathrm{M})$ and compound (11) (12 and $24 \mu \mathrm{M})$. The reaction was monitored every $5 \mathrm{~min}$ for a total time of $25 \mathrm{~min}$ and measured at $405 \mathrm{~nm}$ by a microplate reader. Each experiment was performed in triplicate. The $\mathrm{K}_{i}$ value was estimated by constructing a secondary plot which is plotted by the slopes of the double-reciprocal lines versus inhibitor concentration.

\subsection{Assay for Anti-Adipogenic Activity}

\subsubsection{Cell Culture and Adipocyte Differentiation}

Mouse embryonic preadipocyte 3T3-L1 cells were cultured in DMEM containing 10\% FBS, 100 units/mL of penicillin/streptomycin, and $2 \mathrm{mmol} / \mathrm{L}$ of L-glutamine under humidified conditions of $5 \% \mathrm{CO}_{2}$ at $37{ }^{\circ} \mathrm{C}$ until $70-80 \%$ confluence was reached. For differentiation into adipocyte, preadipocyte 3T3-L1 cells were incubated with differentiation media composed of 10\% FBS, $0.5 \mathrm{mM}$ isobutylmethylxanthine, $1 \mu \mathrm{M}$ dexamethasone, and $5 \mu \mathrm{g} / \mathrm{mL}$ insulin in DMEM with or without test compound for 2 days. Then, the differentiation media was replaced with culture media containing $5 \mu \mathrm{g} / \mathrm{mL}$ of insulin. After further incubation for 2 days, the cells were maintained in complete DMEM, which was changed every 2 days until adipocytes containing lipid droplets were observed under microscope [40].

\subsubsection{Determination of Cytotoxicity}

To evaluate the effect of $D$. delacourii extracts on cell viability, 3T3-L1 preadipocytes were seeded into 96-well plates at density of $2 \times 10^{3}$ cells/well and allowed to attach overnight at $37^{\circ} \mathrm{C}$. Then, the cells were further cultured with extracts $(5 \mu \mathrm{g} / \mathrm{mL})$, compounds $(20 \mu \mathrm{M})$, or left untreated for $48 \mathrm{~h}$ before adding of $0.45 \mathrm{mg} / \mathrm{mL}$ MTT solution to assess cell viability. After incubation for $3 \mathrm{~h}$ at $37^{\circ} \mathrm{C}$ and kept from light, the optical density (OD) of the purple formazan product dissolved in DMSO was measured at $570 \mathrm{~nm}$ using a microplate reader (Anthros, Durham, NC, USA). The relative OD ratio of treated to non-treated cells was presented as percentage cell viability [50].

The cytotoxicity of $D$. delacourii extracts was confirmed via cell death detection using costaining of Hoechst 33342 and propidium iodide. After $48 \mathrm{~h}$ incubation with indicated 
treatment, the cells were further incubated with nuclear staining solution containing $2 \mu \mathrm{g} / \mathrm{mL}$ of Hoechst33342 and $1 \mu \mathrm{g} / \mathrm{mL}$ of propidium iodide for $30 \mathrm{~min}$. The mode of cell death was observed under a fluorescence microscope (Olympus IX51 with DP70, Olympus Corp., Shinjuku-ku, Tokyo, Japan).

\subsubsection{Quantification of Cellular Lipid Content Using Oil Red O Staining}

The lipid droplets presenting in differentiated adipocytes were detected via oil red $\mathrm{O}$ staining. After the differentiation process, 3T3-L1 cells were fixed with $10 \%$ formalin for $45 \mathrm{~min}$ and further incubated with oil red $\mathrm{O}$ solution at room temperature for $1 \mathrm{~h}$. After washing with $60 \%$ isopropanol for three times, oil red O-stained cells were captured using a Nikon Ts2 inverted optical microscope (Tokyo, Japan). For quantification, cellular oil red $\mathrm{O}$ was extracted using absolute isopropanol for measurement of OD at $570 \mathrm{~nm}$ by microplate reader (Anthros, Durham, NC, USA) [51]. The percentage of oil red O staining was calculated relative to the total protein content determined by BCA assay [52].

\subsubsection{Western Blot Analysis}

After the indicated treatment, 3T3-L1 cells were washed with phosphate-buffered saline (PBS, pH 7.4), then the cell membranes were broken using RIPA buffer supplemented with a protease inhibitor cocktail. After incubation on ice for $45 \mathrm{~min}$, the cell lysates were centrifuged at $12,000 \mathrm{rpm}$ at $4{ }^{\circ} \mathrm{C}$ for $15 \mathrm{~min}$ to collect the clear supernatant containing cellular protein, which was measured for total protein content using a BCA assay kit. The total protein $(30 \mu \mathrm{g})$ from each sample was loaded and separated onto 10\% sodium dodecyl sulfate-polyacrylamide gel electrophoresis (SDS-PAGE). Subsequently, the separated proteins were transferred onto nitrocellulose membranes, which were blocked with 5\% skim milk in TBST buffer (Tris-buffered saline with Tween 20, pH 7.2) and further immunoblotted with primary antibodies against p-Akt (Thr308), Akt, p-GSK3 $\beta$ (Ser9), GSK3 $\beta, \mathrm{p}-\mathrm{AMPK} \alpha$ (Thr172), AMPK $\alpha, \mathrm{p}-\mathrm{AMPK} \beta 1$ (Ser128), AMPK $\beta 1 / 2$, p-ACC (Ser79), $\mathrm{ACC}, \operatorname{PPAR} \gamma, \mathrm{C} / \mathrm{EBP} \alpha$, and $\beta$-actin at $4{ }^{\circ} \mathrm{C}$ overnight. Before immersion in horseradish peroxidase (HRP)-linked secondary antibody at room temperature for $2 \mathrm{~h}$, the membranes were washed with TBST for $7 \mathrm{~min}$, three times. The reactive protein signals exposed with chemiluminescent substrates were captured and quantified using Chemiluminescent ImageQuant LAS 4000 (GE Healthcare Bio-Sciences AB, Björkgatan, Uppsala, Sweden).

\subsection{Statistical Analysis}

All data are expressed as means \pm standard deviation (SD) obtained from three independent experiments. Statistical analysis was performed using GraphPad Prism 8.0.2 (GraphPad Software Inc., San Diego, CA, USA) with one-way ANOVA. Differences with $p$ value $<0.05$ were considered to be statistically significant.

\section{Conclusions}

In this study, 11 compounds were isolated from the ethyl acetate extract of $D$. delacourii. Two dimeric phenanthrene derivatives, phoyunnanin E (10) and phoyunnanin C (11), revealed the most potent $\alpha$-glucosidase inhibition when compared with a positive control, acarbose. An enzyme kinetic study performed on them indicated non-competitive inhibitors. Regarding anti-adipogenic activity, densifloral B (3) showed the most potent activity when compared with a positive control, oxyresveratrol. The anti-adipogenic properties of densifloral B (3) were attributed to the downregulation of PPAR $\gamma$ and C/EBP $\alpha$ expression through the modulation of Akt-related pathways including the Akt/GSK3 $\beta$ and Akt/AMPK-ACC signals. The findings obtained from this study demonstrate the evaluation of $\alpha$-glucosidase inhibitory activity and anti-adipogenic effect of the Dendrobium delacourii plant, which can be used for the management of diabetes and obesity. 


\begin{abstract}
Author Contributions: B.S. conceived, designed, and supervised the research project, as well as preparing and editing the manuscript; C.C. supervised the anti-adipogenic activity and prepared the manuscript; M.T.T. performed the experiments and prepared the manuscript; H.E.E.K. and J.Q.L.N. assisted in anti-adipogenic activity; N.C. supervised the $\alpha$-glucosidase inhibition assay; K.L. provided comments and suggestions on the preparation of the manuscript. All authors have read and agreed to the published version of the manuscript.
\end{abstract}

Funding: This research is funded by Thailand Science research and Innovation Fund Chulalongkorn University (CU_FRB65_hea (57)066_33_10). C.C. is grateful to the Faculty of Pharmaceutical Sciences, Chulalongkorn University, for a research fund (Phar2564-RG008).

Institutional Review Board Statement: Not applicable.

Informed Consent Statement: Not applicable.

Data Availability Statement: All data presented in this study are available in the article.

Acknowledgments: M.T.T. is grateful to the Graduate School, Chulalongkorn University, for a CUASEAN Ph.D. scholarship.

Conflicts of Interest: The authors declare no conflict of interest.

Sample Availability: Samples of the compounds are not available from authors.

\title{
References
}

1. WHO. Definition, Diagnosis and Classification of Diabetes Mellitus and Its Complication (Part 1); World Health Organization: Geneva, Swizerland, 1999; pp. 2-32.

2. Bischoff, H. Pharmacology of $\alpha$-glucosidase inhibition. Eur. J. Clin. Investig. 1994, 24, 3-10.

3. Peng, X.; Zhang, G.; Liao, Y.; Gong, D. Inhibitory kinetics and mechanism of kaempferol on $\alpha$-glucosidase. Food Chem. 2016, 190, 207-215. [CrossRef] [PubMed]

4. $\quad$ Nhiem, N.X.; Kiem, P.V.; Minh, C.V.; Ban, N.K.; Cuong, N.X.; Tung, N.H.; Ha, L.M.; Ha, D.T.; Tai, B.H.; Quang, T.H.; et al. $\alpha$-Glucosidase inhibition properties of cucurbitane-type triterpene glycosides from the fruits of Momordica charantia. Chem. Pharm. Bull. 2010, 58, 720-724. [CrossRef] [PubMed]

5. Butala, M.A.; Kukkupuni, S.K.; Vishnuprasad, C.N. Ayurvedic anti-diabetic formulation Lodhrasavam inhibits alpha-amylase, alpha-glucosidase and suppresses adipogenic activity in vitro. J. Ayurveda. Integr. Med. 2017, 8, 145-151. [CrossRef]

6. Abbasi, F.; Brown, B.W.; Lamendola, C.; McLaughlin, T.; Reaven, G.M. Relationship between obesity, insulin resistance, and coronary heart disease risk. J. Am. Coll. Cardiol. 2002, 40, 937-943. [CrossRef]

7. Tan, H.Y.; Iris, M.Y.; Li, E.T.; Wang, M. Inhibitory effects of oxyresveratrol and cyanomaclurin on adipogenesis of 3T3-L1 cells. J. Funct. Foods 2015, 15, 207-216. [CrossRef]

8. Klein, G.; Kim, J.; Himmeldirk, K.; Cao, Y.; Chen, X. Antidiabetes and anti-obesity activity of Lagerstroemia speciosa. Evid. Based Complement. Altern. Med. 2007, 4, 401-407. [CrossRef]

9. Yun, J.W. Possible anti-obesity therapeutics from nature-A review. Phytochemistry 2010, 71, 1625-1641. [CrossRef]

10. Hwang, J.T.; Park, I.J.; Shin, J.I.; Lee, Y.K.; Lee, S.K.; Baik, H.W.; Park, O.J. Genistein, EGCG, and capsaicin inhibit adipocyte differentiation process via activating AMP-activated protein kinase. Biochem. Biophys. Res. Commun. 2005, 338, 694-699. [CrossRef]

11. Lin, J.; Della-Fera, M.A.; Baile, C.A. Green tea polyphenol epigallocatechin gallate inhibits adipogenesis and induces apoptosis in 3T3-L1 adipocytes. Obes. Res. 2005, 13, 982-990. [CrossRef]

12. Pinent, M.; Blay, M.; Blade, M.C.; Salvado, M.J.; Arola, L.; Ardevol, A. Grape seed-derived procyanidins have an antihyperglycemic effect in streptozotocin-induced diabetic rats and insulinomimetic activity in insulin-sensitive cell lines. Endocrinology 2004, 145, 4985-4990. [CrossRef] [PubMed]

13. Daval, M.; Foufelle, F.; Ferré, P. Functions of AMP-activated protein kinase in adipose tissue. J. Physiol. 2006, 574, 55-62. [CrossRef] [PubMed]

14. Luo, Z.; Zang, M.; Guo, W. AMPK as a metabolic tumor suppressor: Control of metabolism and cell growth. Future Oncol. 2010, 6, 457-470. [CrossRef] [PubMed]

15. Habinowski, S.A.; Witters, L.A. The effects of AICAR on adipocyte differentiation of 3T3-L1 cells. Biochem. Biophys. Res. Commun. 2001, 286, 852-856. [CrossRef] [PubMed]

16. Saha, A.K.; Ruderman, N.B. Malonyl-CoA and AMP-activated protein kinase: An expanding partnership. Mol. Cell Biochem. 2003, 253, 65-70. [CrossRef] [PubMed]

17. Lago, F.; Gómez, R.; Gómez-Reino, J.J.; Dieguez, C.; Gualillo, O. Adipokines as novel modulators of lipid metabolism. Trends Biochem. Sci. 2009, 34, 500-510. [CrossRef]

18. Rizzatti, V.; Boschi, F.; Pedrotti, M.; Zoico, E.; Sbarbati, A.; Zamboni, M. Lipid droplets characterization in adipocyte differentiated 3T3-L1 cells: Size and optical density distribution. Eur. J. Histochem. 2013, 57, e24. [CrossRef] 
19. Kim, J.H.; Lee, S.; Cho, E.J. Flavonoids from Acer okamotoanum inhibit adipocyte differentiation and promote lipolysis in the 3T3-L1 cells. Molecules 2020, 25, 1920. [CrossRef]

20. Kim, G.S.; Park, H.J.; Woo, J.H.; Kim, M.K.; Koh, P.O.; Min, W.; Cho, J.H. Citrus aurantium flavonoids inhibit adipogenesis through the Akt signaling pathway in 3T3-L1 cells. BMC Complement. Altern. Med. 2012, 12, 31. [CrossRef]

21. Kim, H.J.; Yoon, B.K.; Park, H.; Seok, J.W.; Choi, H.; Yu, J.H.; Kim, J.W. Caffeine inhibits adipogenesis through modulation of mitotic clonal expansion and the AKT/GSK3 $\beta$ pathway in 3T3-L1 adipocytes. BMB Rep. 2016, 49, 111. [CrossRef]

22. Stein, S.A.; Lamos, E.M.; Davis, S.N. A review of the efficacy and safety of oral antidiabetic drugs. Expert. Opin. Drug Saf. 2013, 12, 153-175. [CrossRef] [PubMed]

23. Kang, J.G.; Park, C.Y. Anti-obesity drugs: A review about their effects and safety. Diabetes Metab. J. 2012, 36, 13-25. [CrossRef]

24. Paudel, M.R.; Bhattarai, H.D.; Pant, B. Traditionally used medicinal Dendrobium: A promising source of active anticancer constituents. In Orchids Phytochemistry, Biology and Horticulture: Fundamentals and Applications; Springer: Cham, Switzerland, 2020; pp. 1-26.

25. Xu, J.; Han, Q.B.; Li, S.L.; Chen, X.J.; Wang, X.N.; Zhao, Z.Z.; Chen, H.B. Chemistry, bioactivity and quality control of Dendrobium, a commonly used tonic herb in traditional Chinese medicine. Phytochem. Rev. 2013, 12, 341-367. [CrossRef]

26. Cakova, V.; Bonte, F.; Lobstein, A. Dendrobium: Sources of active ingredients to treat age-related pathologies. Aging Dis. 2017, 8 , 827-849. [CrossRef] [PubMed]

27. Cheng, J.; Dang, P.P.; Zhao, Z.; Yuan, L.C.; Zhou, Z.H.; Wolf, D.; Luo, Y.B. An assessment of the Chinese medicinal Dendrobium industry: Supply, demand and sustainability. J. Ethnopharmacol. 2019, 229, 81-88. [CrossRef]

28. Chuakul, W. Ethnomedical uses of Thai Orchidaceous plants. Mahidol J. Pharm. Sci. 2002, 29, 41-45.

29. Fisch, M.H.; Flick, F.H.; Arditti, J. Structure and antifungal activity of hircinol, loroglossol and orchinol. Phytochemistry 1973, 12, 437-441. [CrossRef]

30. Majumder, P.L.; Sen, R.C. Structure of moscatin-A new phenanthrene derivative from the orchid Dendrobium moscatum. Indian J. Chem. 1987, 26B, 18-20.

31. Fan, C.; Wang, W.; Wang, Y.; Qin, G.; Zhao, W. Chemical constituents from Dendrobium densiflorum. Phytochemistry 2001, 57, 1255-1258. [CrossRef]

32. Ono, M.; Ito, Y.; Masuika, C.; Koga, H.; Nohara, T. Antioxidative constituents from Dendrobii Herba (stems of Dendrobium spp.). Food Sci. Technol. Int. 1995, 1, 115-120.

33. Leong, Y.W.; Kang, C.C.; Harrison, L.J.; Powell, A.D. Phenanthrenes, dihydrophenanthrenes and bibenzyls from the orchid Bulbophyllum vaginatum. Phytochemistry 1997, 44, 157-165. [CrossRef]

34. Chen, Y.; Xu, J.; Yu, H.; Qing, C.; Zhang, Y.; Wang, L.; Liu, Y.; Wang, J. Cytotoxic phenolics from Bulbophyllum odoratissimum. Food Chem. 2008, 107, 169-173. [CrossRef]

35. Yang, M.; Zhang, Y.; Chen, Y. A new (propylphenyl) bibenzyl derivative from Dendrobium williamsonii. Nat. Prod. Res. 2017, 32, 1699-1705. [CrossRef] [PubMed]

36. Guo, X.Y.; Wang, J.; Wang, N.L.; Kitanaka, S.; Yao, X.S. 9, 10-Dihydrophenanthrene derivatives from Pholidota yunnanensis and scavenging activity on DPPH free radical. J. Asian Nat. Prod. Res. 2007, 9, 165-174. [CrossRef] [PubMed]

37. Guo, X.Y.; Wang, J.; Wang, N.L.; Kitanaka, S.; Liu, H.W.; Yao, X.S. New stilbenoids from Pholidota yunnanensis and their inhibitory effects on nitric oxide production. Chem. Pharm. Bull. 2006, 54, 21-25. [CrossRef]

38. Chougale, A.D.; Ghadyale, V.A.; Panaskar, S.N.; Arvindekar, A.U. Alpha glucosidase inhibition by stem extract of Tinospora cordifolia. J. Enzyme Inhib. Med. Chem. 2009, 24, 998-1001. [CrossRef] [PubMed]

39. Ghadyale, V.; Takalikar, S.; Haldavnekar, V.; Arvindekar, A. Effective control of postprandial glucose level through inhibition of intestinal alpha glucosidase by Cymbopogon martinii (Roxb.). Evid. Based Complement. Altern. Med. 2012, 2012, 372909. [CrossRef]

40. Yang, M.H.; Chin, Y.W.; Chae, H.S.; Yoon, K.D.; Kim, J. Anti-adipogenic constituents from Dioscorea opposita in 3T3-L1 cells. Bio. Pharm. Bull. 2014, 37, 1683-1688. [CrossRef]

41. Sarjeant, K.; Stephens, J.M. Adipogenesis. Cold Spring Harb. Perspect. Biol. 2012, 4, a008417. [CrossRef]

42. Lee, H.W.; Rhee, D.K.; Kim, B.O.; Pyo, S. Inhibitory effect of sinigrin on adipocyte differentiation in 3T3-L1 cells: Involvement of AMPK and MAPK pathways. Biomed. Pharmacother. 2018, 102, 670-680. [CrossRef]

43. Ahmad, B.; Serpell, C.J.; Fong, I.L.; Wong, E.H. Molecular mechanisms of adipogenesis: The anti-adipogenic role of AMP-activated protein kinase. Front. Mol. Biosci. 2020, 7, 76. [CrossRef] [PubMed]

44. Kang, M.C.; Ding, Y.; Kim, H.S.; Jeon, Y.J.; Lee, S.H. Inhibition of adipogenesis by diphlorethohydroxycarmalol (DPHC) through AMPK activation in adipocytes. Mar. Drugs 2019, 17, 44. [CrossRef] [PubMed]

45. Shao, Y.; Yuan, G.; Zhang, J.; Guo, X. Liraglutide reduces lipogenetic signals in visceral adipose of db/db mice with AMPK activation and Akt suppression. Drug Des. Devel. Ther. 2015, 9, 1177-1184. [CrossRef] [PubMed]

46. Liu, X.; Yao, Z. Chronic over-nutrition and dysregulation of GSK3 in diseases. Nutr. Metab. 2016, 13, 49. [CrossRef]

47. Manning, B.D.; Toker, A. AKT/PKB signaling: Navigating the network. Cell 2017, 169, 381-405. [CrossRef] [PubMed]

48. Jope, R.S.; Bijur, G.N. Mood stabilizers, glycogen synthase kinase-3 $\beta$ and cell survival. Mol. Psychiatry 2002, 7, S35-S45. [CrossRef]

49. Chatsumpun, N.; Sritularak, B.; Likhitwitayawuid, K. New biflavonoids with $\alpha$-glucosidase and pancreatic lipase inhibitory activities from Boesenbergia rotunda. Molecules 2017, 22, 1862. [CrossRef] [PubMed] 
50. Ono, M.; Fujimori, K. Antiadipogenic effect of dietary apigenin through activation of AMPK in 3T3-L1 cells. J. Agric. Food Chem. 2011, 59, 13346-13352. [CrossRef]

51. Borah, A.K.; Kuri, P.R.; Singh, A.; Saha, S. Anti-adipogenic effect of Terminalia chebula fruit aqueous extract in 3T3-L1 preadipocytes. Pharmacogn. Mag. 2019, 15, 197-204.

52. He, F. BCA (bicinchoninic acid) protein assay. Bio-protocol 2011, 1, e44. [CrossRef] 